\title{
European Policy and Markets Did Policy Initiatives Stem the Sovereign Debt Crisis in the Euro Area?
}

Bergman, U. Michael; Hutchison, Michael M.; Hougaard Jensen, Svend E.

Document Version

Accepted author manuscript

Published in:

European Journal of Political Economy

DOI:

10.1016/j.ejpoleco.2018.06.003

Publication date:

2019

License

CC BY-NC-ND

Citation for published version (APA):

Bergman, U. M., Hutchison, M. M., \& Hougaard Jensen, S. E. (2019). European Policy and Markets: Did Policy Initiatives Stem the Sovereign Debt Crisis in the Euro Area? European Journal of Political Economy, 57, 3-21. https://doi.org/10.1016/j.ejpoleco.2018.06.003

Link to publication in CBS Research Portal

\section{General rights}

Copyright and moral rights for the publications made accessible in the public portal are retained by the authors and/or other copyright owners and it is a condition of accessing publications that users recognise and abide by the legal requirements associated with these rights.

Take down policy

If you believe that this document breaches copyright please contact us (research.lib@cbs.dk) providing details, and we will remove access to the work immediately and investigate your claim. 


\section{European Policy and Markets: Did Policy Initiatives Stem the Sovereign Debt Crisis in the Euro Area? \\ U. Michael Bergman, Michael M. Hutchison, and Svend E. Hougaard Jensen}

Journal article (Accepted manuscript*)

\section{Please cite this article as:}

Bergman, U. M., Hutchison, M. M.., \& Hougaard Jensen, S. E. (२०19). European Policy and Markets: Did Policy Initiatives Stem the Sovereign Debt Crisis in the Euro Area? European Journal of Political Economy, 57, 3-21. https://doi.org/10.1016/j.ejpoleco.2018.06.003

DOI: 10.1016/j.ejpoleco.2018.06.003

* This version of the article has been accepted for publication and undergone full peer review but has not been through the copyediting, typesetting, pagination and proofreading process, which may lead to differences between this version and the publisher's final version AKA Version of Record.

Uploaded to CBS Research Portal: August 2019

(C) 2019. This manuscript version is made available under the CC-BY-NC-ND 4.0 license http://creativecommons.org/licenses/by-nc-nd/4.0/ 


\title{
European policy and markets: Did policy initiatives stem the sovereign debt crisis in the Euro Area?"
}

\author{
By \\ U. Michael Bergman \\ Department of Economics, University of Copenhagen \\ Øster Farimagsgade 5, Building 26, DK-1353 Copenhagen K, Denmark \\ Michael.Bergman@econ.ku.dk \\ Michael M. Hutchison \\ Department of Economics, University of California, Santa Cruz \\ Santa Cruz, CA 95064 USA \\ hutch@ucsc.edu \\ Svend E. Hougaard Jensen \\ Department of Economics, Copenhagen Business School \\ Porcelaenshaven 16A, 2000 Frederiksberg C, Denmark \\ shj.eco@cbs.dk
}

\begin{abstract}
We investigate how European policy initiatives influenced market assessments of sovereign default risk and banking sector fragility during the sovereign debt crisis in four adversely affected countries - Portugal, Ireland, Spain and Italy. We focus on three broad groups of policies: (a) ECB policy actions (monetary and financial support), (b) EU programs (financial and fiscal rules as well as financial support in crisis countries), and (c) domestic austerity programs. We measure immediate market impact effects: what policies changed risk perceptions, using CDS spreads on sovereign bonds and banks in this assessment. We employ dynamic panel and event study methodologies in the empirical work. We find that a number of programs initially stabilized sovereign and bank bond markets (e.g. Outright Monetary Transactions program), although announcement and implementation impacts on markets differed in some cases (e.g. second Covered Market Bond Program). Actions designed to shore up sovereign markets often lowered risk assessments in bank bond markets and policies designed to ensure safety and soundness of the European banking system in some cases significantly impacted sovereign debt markets. Finally, a number of policies designed to stabilize markets had surprisingly little immediate impact on either sovereign or bank bond market risk assessments.
\end{abstract}

Keywords: EU policy initiatives ; Transmission of policy news; Euro crisis;

JEL codes: E42, E44, F36, F42, G14, H63

June 2018

- We are grateful for helpful comments from Francesca D'Auria, Petra Geraats, Britta Niehof, Plamen Nikolov and "Fiscal Frameworks in Europe: Background and Perspectives" conference (Danmarks Nationalbank, 1-2 June 2017) participants, especially our discussant, Massimo Giuliodori. We also thank two anonymous referees for helpful comments and suggestions. We thank Xin Li for excellent research assistance. 


\section{Introduction}

In the aftermath of the global financial crisis, government budget deficits and debt ratios in many countries in the Euro Area (EA) climbed to the highest levels seen in the post-war period and banks were incurring large losses. Market interest rates and credit default swap (CDS) spreads on sovereign debt and bank liabilities increased sharply in response, signaling lack of confidence in fiscal (and other) policies and bank solvency. The European sovereign debt crisis was characterized by tumultuous markets and technical defaults (Cyprus and Greece) or near-default by other EA countries (Ireland and Portugal) and widespread bank fragility. Against this background, policymakers responded with a multitude of programs designed to provide short-term liquidity to stabilize EA countries' sovereign debt markets, provide governments with short-term financing, restore long-term sustainable public finances, support banks, and restore confidence. Programs by the ECB, EU and IMF — the "troika" — and national governments were announced and implemented.

European policy programs were announced successively over time, somewhat hesitantly at first, and gradually grew in size and breath as the sovereign debt crisis continued and intensified. It is evident that the cumulative impact of policies, culminating with the ECB's Outright Monetary Transactions (OMT) program, eventually had the desired effect of quelling, if not resolving, the sovereign debt crisis. However, each policy program in itself may have had some marginal contribution to stabilizing markets.

This paper addresses how various European policy announcements, designed to quell the sovereign debt crisis, changed market assessments of sovereign and bank bond default risk. Immediate market reactions to policy announcements are one metric of gauging whether these policies were perceived as helpful in stabilizing markets. Using this metric, we shed light on three fundamental questions. Firstly, which of the ECB (monetary and financial support), EU (financial, fiscal rules and financial support in crisis countries), and domestic government (austerity) programs were most effective (ineffective) in immediately stabilizing sovereign debt markets? Secondly, which of these programs were initially most effective (ineffective) in stabilizing market concerns over bank fragility? And, thirdly, were there unintended market consequences of the programs apparent at the onset? That is, were program announcements targeted toward banks (sovereign debt) helpful in reducing the immediate anxiety about sovereign debt (banks)? Measuring reactions to policy announcements indicate how market participants initially evaluated the likelihood of program success and updated default risk perceptions.

Using panel regression and event-study frameworks, we investigate the response of sovereign and bank CDS spreads to European policy announcements. The linkages between sovereign and bank risks are evident, as we show below, and are a motivating factor behind moves to create a full banking union in 
Europe. We divide policy actions into several policy distinguish categories, and whether they are designed to stabilize sovereign debt markets or provide support to banks (liquidity and capital injections).

Section 2 reviews the literature on how policy actions are incorporated into market perceptions of default risk. Section 3 evaluates CDS spreads as a measure of sovereign and bank risk perceptions, linkages between sovereign and bank risk, and the empirical methodology and data for our study. This is followed, in Section 4, by a presentation of our empirical results on market perceptions of risk and policy impact effects. This section reports our results on how markets price sovereign and bank risk in four European countries (Portugal, Ireland, Italy and Spain), whether European policy measures affected market pricing of risk and how banking fragility affects risk perceptions. Section 5 concludes and discusses policy implications.

\section{Market Perceptions of Default Risk}

\subsection{How do markets evaluate policy actions, sovereign default risk and bank fragility?}

Market signals provide both surveillance as well as direct and automatic sanctions in terms of higher borrowing costs in many financial markets, including the sovereign debt and corporate bond markets, when policies or continued operations are perceived as unsustainable. Market responses also serve as important indicators of the perceived credibility of government and central bank announcements, such as new policies, regulations and debt purchases, designed to shore up fiscal sustainability, stabilize sovereign and bank debt markets, and restore confidence. The question we address is whether market prices systematically and quickly respond to European policy actions designed to stabilize sovereign debt markets and banks. In particular, do financial markets quickly respond systematically and predictably to policy announcements about ECB policy actions, new EU regulations and fiscal rules, financial assistance to governments in distress, and domestic budget austerity measures that should, in principle, shore up debt sustainability and bank solvency?

\subsection{ECB actions}

There is a large literature on these topics, addressing these issues from several vantage points. One group of studies investigates ECB actions. Gerlach-Kristen (2015), for example, investigates whether ECB open market operations reduced CDS spreads on bank and sovereign bonds. It is found that (a) purchases under the Covered Bond Purchase Programme reduced spreads, as did the announcement of the Securities Market Programme (SMP), and (b) actual SMP purchases raised spreads, conjecturing that markets may have seen them as a sign of policymaker concern about the financial system.

Altavilla, Giannone and Lenza (2016) focus on announcements of the ECB's Outright Monetary Transactions (OMT) program and the effect on Treasury bond markets. They regress (in the sample from January 2007 to February 2013) changes in government bond yields on a vector of event dummies and financial news. The events are the three announcements regarding the OMT and that occurred between July 
and September 2012. Using high frequency data, they find that the OMT announcements decreased the Italian and Spanish two-year government bond yields by about 2 percentage points, while leaving unchanged the bond yields of the same maturity in Germany and France.

Focusing on banks, Markman and Zietz (2017) also examine the effectiveness of the Eurosystem's Covered Bond Purchase Programs. They consider the terms of the spread tightening of euro-denominated covered bonds against those issued by British banks (which do not benefit from the program), which serve as the control group. This study uses weekly data from the beginning of 2006 to the middle of 2015. It makes use of an unobserved components model (structural time series) framework. The announcement effects identified by prior studies for the first Covered Bond Purchase Program are confirmed, but effects of the subsequent two programs differ. Their implementation tends to widen covered bond yields, contrary to the Eurosystem's objectives, but in line with liquidity expectations.

Ricci (2015) also assesses the impact of ECB monetary policy announcements, focusing on the stock prices of large European banks. He conducts an event study measuring cumulated abnormal returns (CARs) around the announcements over June 2007-June 2013, and a regression analysis aimed at identifying the determinants of CARs. It is found that banks were more sensitive to non-conventional measures than to interest rate decisions, that the same type of intervention may have a different impact depending on the stage of the crisis, and that banks with weaker balance sheets and operating with high-risk were more sensitive to monetary policy interventions.

\subsection{Fiscal actions, financial assistance and other policies}

In terms of fiscal actions, Alter and Beyer (2012) analyze specific news announcements and find that the establishment of the European Financial Stability Facility (EFSF) - created as a temporary crisis resolution mechanism by the EA in June 2010, providing financial assistance to Ireland, Portugal and Greece - and the two long-term refinancing operations (LTROs) decided upon in December 2011, tended to reduce contagion across European markets somewhat. On the other hand, the bailout of the Spanish bank Bankia had the opposite effect, and tended to increase contagion.

More broadly, Thornton and Vasilakis (2015) examine whether adopting a numerical fiscal rule (FR) framework to guide fiscal policy helps reduce sovereign risk premia in a sample of advanced and developing countries for 1985-2012. They address the self-selection problem of policy adoption by applying propensity score matching methods, and find that adopting fiscal rules reduces sovereign risk premia. Specifically, they test the impact of FRs adoption on sovereign risk premia by examining developments in the spread between the interest rate at which a country borrows and the "risk free" rate, which they define as the yield on longterm U.S. Treasury bonds. They employ two treatment groups: One group of 33 advanced and developing countries that had adopted a numerical rule on the fiscal balance by the end of 2012, and another group of 27 advanced and developing countries that had adopted a rule on the stock of public debt (with overlap between 
the two groups as many countries adopted both rules). The control group comprises 29 non-FRs adopting countries. Their results indicate that the adoption of FRs on the fiscal balance and/or the stock of public debt resulted in a statistically significant reduction in sovereign risk premia, suggesting that FRs help build policy credibility, reducing the risk premia paid to compensate lenders for the possibility of government default.

Also on fiscal actions, Feld et al. (2017) analyze the effects of a credible no-bailout policy and stringent sub-national FRs on the risk premia of Swiss subnational government bonds in the period from 1981 to 2007. In July 2003, the Swiss Supreme Court decided that the canton of Valais is not liable for municipal debt. This landmark decision reduced cantonal risk premia by about 26 basis points and cut the link between cantonal risk premia and the financial situation of the municipalities that existed before. The result demonstrates that a not fully credible no-bailout commitment can entail high costs for the potential guarantor. Additionally, strong and credible balanced budget rules reduce risk premia. They also find positive market reactions to unexpected changes in the programs' eligibility criteria.

\subsection{Financial assistance programs and other policies}

In terms of financial assistance, Klomp (2013) examines the effectiveness of the financial sector rescue packages provided by the national governments during the 2008 Global Financial Crisis. He finds financial sector rescue package announcements reduce credit default premiums on banks, but the effect varies across banks: most interventions do not decrease premiums on intermediate to low-risk banks, while they do reduce premiums on high-risk banks. He also finds that interventions aimed at specific financial institutions are more effective in reducing banking risk than broad interventions taken to stabilize the financial market as a whole.

Grammatikosa et al. (2015) explore the impacts of key policy actions by US and European authorities on stock returns of systemically important banks in Europe and US around the Global Financial Crisis. They find that US policy announcements had a stronger impact on the European and US banking industry than European policy announcements. In particular, the announcements of monetary policies by the US authorities were accompanied by higher abnormal returns compared to related announcements of European authorities. But both US and European policy announcements increased return volatility during the crisis.

More broadly, Aït-Sahalia et al. (2012) examine the impact of macroeconomic and financial sector policy announcements in the United States, the United Kingdom, the euro area and Japan on interbank credit and liquidity risk premia during June 1, 2007-March 31, 2009. They measure credit and risk premia by the Libor-OIS spread, and investigate responses to a variety of policy announcements across countries. They find that policy interventions were associated with a reduction in interbank risk premia, most significantly for recapitalization programs. By contrast, decisions to bail out individual banks in an ad hoc manner or let them fail were accompanied by a significant rise in interbank risk premia. Moreover, most policy announcements had international spillovers. 
Mink and de Haan (2013) consider the impact of Greek news including the Greek bailouts on bank stock prices. They look at 48 European banks in 2010. They find that Greek news did not affect bank stock prices. However, the Greek bailout had a tremendous impact with stronger effects on banks heavily exposed to Greek debt. What is interesting is that even banks not exposed to GIPS (Greece, Italy, Portugal and Spain) debt also were significantly affected.

The relationship between CDS spreads and fundamentals, including fiscal stance, is studied by Aizenman, Hutchison and Jinjarak (2012) who find that fundamentals explain spreads but that default risk in periphery euro area countries are priced too high given current fundamentals during the crisis period, and perhaps too low during the pre-crisis period. The European Commission (2012) also considered the determinants of CDS spreads in Europe, including fiscal stance. Their results suggest fiscal balance and other macro variables significantly affect the spreads.

The overall conclusion from the empirical literature studying the effects of policy news announcements is that market prices respond strongly. However, the specific literature on European program initiatives during the sovereign debt crisis is small but growing, and questions remain about how markets respond to new programs, regulations and other policy announcements by the ECB and the European Commission.

\section{Data, Methodology and Testable Hypotheses}

\subsection{Measuring market responses of default risk}

In this section, we describe our approach to analyzing the effects of policy announcements. Building on the literature discussed in the previous section we focus on the response of CDS spreads to European policy announcements. Our main contributions are to examine how sovereign and bank debt markets in the EU countries at the center of the sovereign debt crisis - Italy, Ireland, Portugal and Spain (IIPS) - responded to a host of ECB actions, EU policy and regulatory changes, and domestic austerity policies. ${ }^{1}$

Our analysis of the impact of news announcements on interest spreads is influenced by Dooley and Hutchison (2009) who study the transmission of news from the US on emerging markets. Collecting news announcements and categorizing these into different groups allow them to study the effects of on a selection of emerging markets. ${ }^{2}$ Our work is also influenced by Beetsma, Giuliodori, de Jong and Widijanto (2012) who study the transmission of news on GIIPS countries on euro area and non-euro area Member States.

We measure the market perception of sovereign and bank default risk by the spreads on sovereign and bank CDS. CDS instruments are mainly transacted in over-the-counter (OTC) derivative markets. The spreads represent the quarterly payments that must be paid by the buyer of CDS to the seller for the contingent claim

\footnotetext{
${ }^{1}$ Greece was of course also at the center of the sovereign debt crisis and defaulted. Greece, however, is not included in the present study as its circumstances represent an extreme and special case.

${ }^{2}$ The main result from their study is that news announcements do lead to responses in CDS spreads. For example, the Lehman Brothers failure and associated news raised CDS spreads in all 14 countries studied and the effect ranges from 7 basis points increase for the Chinese sovereign spread to over 100 basis points for Argentinian spreads.
} 
in the case of a credit event, in this case non-payment (or forced restructuring) of sovereign debt, and is therefore an excellent proxy for market-based default risk pricing.

The total CDS market grew from about 10 trillion USD in 2004, when statistics were first systematically reported, to a peak prior to the global financial crisis of almost 60 trillion USD in 2007, and then fell sharply to around 32 trillion USD in mid-2011 according to Bank of International Settlement (BIS) surveys. The share of sovereign CDS has grown since 2008 from around 15\% (10\%) to almost 25\% (20\%) in December 2011 of total net notional (total gross notional) amount (International Organization of Securities Commission, 2012).

Sovereign CDS provide a market-based real time indicator of sovereign credit quality and default risk. We consider sovereign CDS spreads with five-year maturities, as this is the most liquid part of the CDS market. Despite the low probability of a credit event in most advanced economies, CDS markets are still active in most markets as buyers can use the sovereign CDS as a hedge and for mark-to-market response. Buyers of the sovereign CDS may or may not own the underlying government bonds. The latter case is termed 'naked' sovereign CDS, and frequently labelled as a speculation.

Daily data on CDS prices are taken from Markit. ${ }^{3}$ The data are CDS spreads in USD. The quoting convention for CDS is the annual premium payment as a percentage of the notional amount of the reference obligation. The sovereign CDS spreads are reported in basis points, with a basis point equal to $\$ 1,000$ to insure $\$ 10$ million of debt. ${ }^{4}$

Figure 1 shows daily observations of sovereign CDS spreads in the 16 EMU countries (there is no CDS spread for Luxembourg) from January 1, 2001 until September 13, 2012. ${ }^{5}$ To illustrate the large differences across the countries we use the same scale for all countries except Greece (the upper left graph). It is a striking feature in Figure 1 (and Figure 2) that CDS spreads are almost constant until the failure of Lehman Brothers. As the credit crunch developed, CDS spreads in all EMU countries started to rise and when the credit crunch later developed into a European debt crisis, CDS spreads in the GIIPS countries and in some of the periphery countries also became affected. The Estonian CDS spread increased considerably during the 2008 crisis, much more than in the GIIPS countries. The Cypriot CDS spread became heavily affected from 2010 and onwards as a consequence of its close connections to Greece. The CDS spread increased to similar levels as the Portuguese spread as can be seen in Figure 1. Core EMU countries were not affected to the same degree as can be seen in the lower right graph. It increased somewhat. Even among these countries

\footnotetext{
${ }^{3}$ Markit receives contributed CDS data from market makers from their official books and records. According to the company, Markit "cleans" this data, testing it "...for stale, flat curves, outliers and inconsistent data". If a contribution fails any one of these tests, they discard it. Markit states that they ensure superior data quality for an accurate mark-to-market and market surveillance.

${ }^{4}$ For example, a spread of 197 basis points means that it costs 197,000 USD to insure against 10,000,000 in sovereign debt for 10 years; $1.97 \%$ of notional amount needs to be paid each year, so $0.0197 \times 10$ million $=\$ 197,000$ per year.

${ }^{5}$ The reason why we end our sample on September 13, 2012, is that this allows us to study the short-run effects of the program on CDS spreads and at the same time taking into account that this decision constituted a significant change or a regime change in the EA as has been argued by, e.g., De Grauwe (2013).
} 
there are some notable differences. Belgium and Austria were more affected than other core countries and France somewhat more than Germany and the Netherlands.

These developments can be compared to EU countries not participating in the monetary union. Figure 2 shows the CDS spread for the remaining 10 EU countries. We are using the same scale as for the EA countries except Greece in Figure 1. Looking first at the 6 East European countries we find a strong convergence in CDS spreads with other EU countries: a rise during the credit crunch and high CDS spreads during the 2009 to 2010 period. The Czech Republic stands out as an exception in this group with persistently lower spreads, comparable to the group of outsiders shown in the lower graph.

Figure 3 shows sovereign CDS spreads for Spain and Ireland. Bank CDS spreads and Fitch Rating downgrading of both sovereigns and banks in these two countries is also shown in the figure. ${ }^{6}$ We show the CDS spread for two banks in Spain and one bank in Ireland. In accordance with the CDS spreads for the sovereigns, we use spreads on five-year senior debt for the banks. Clearly, bank and sovereign CDS spreads are highly correlated, usually moving in the same direction simultaneously.

However, credit rating downgrades on sovereigns are usually followed by credit downgrades of banks, while not responding much to their own credit downgrades, i.e., sovereign downgrades increase the likelihood of a bank credit downgrade. Fitch Rating publications explaining credit rating changes also suggest banks are often downgraded as a result of an earlier downgrade of the sovereign.

Overall, the CDS data suggests that both EMU countries and EU countries without the euro have been greatly affected by the crisis; "outsider" status has not insulated the non-Euro economies from shocks related to the credit crunch and the debt crisis. EU countries are highly integrated regardless of whether they have adopted the euro.

In addition, it is evident that sovereign risk and bank risk are closely connected. This is shown more formally in Table 1, motivating our exploration of how policy actions are transmitted to both markets. The table shows the contemporaneous correlation (with t-statistic and probability) between sovereign CDS spreads and bank CDS spreads (in first differences) as well as Granger causality tests between these two series. Two banks are considered for Ireland and one bank each for Portugal, Spain and Italy. Two lags of daily data are used in the Granger tests.

High contemporaneous correlations are evident in most cases between sovereign and bank CDS spread changes. In four of the five cases the correlations between CDS spreads range from 0.26-0.75, and the single (low) outlier has a correlation of 0.04 (Bank of Ireland and Irish sovereign CDS). All correlations are positive and, except in one case, statistically significant, indicating strong linkages between the two measures of default risk. The Granger tests indicate two-way feedback is strong: sovereign CDS "Granger cause” bank CDS, and bank CDS “Granger cause” sovereign CDS.

\footnotetext{
${ }^{6}$ We use five-year senior CDS spreads for banks downloaded from Bloomberg and Reuters.
} 
The news announcement variables are collected from four different sources. First, we use several chronologies of the recent financial crisis and the key developments in the European economies including policy measures both at a national level as well as on a pan-European level; "Key dates in financial crisis" published by the ECB, "Timeline: The unfolding Eurozone crisis" published by BBC, and "Europe's Debt Crisis" published by Wall Street Journal, "Euro crisis" published by Bruegel (prepared by Christophe Gouardo in cooperation with Jean Pisani-Ferry), and "European Sovereign Debt Crisis: Overview, Analysis, and Timeline of Major Events" published by Enterprising Investor. In addition to these sources we use Bloomberg news announcements.

From these chronologies, we identify 276 events representing 21 policy news announcement types. These announcements are grouped into 11 broad policy categories for some of the analysis. Table 2 provides a list of the 21 types of policy news types and specific examples of the announcements. ${ }^{7}$ The policy categories, and broad criteria for inclusion, are:

- Domestic Austerity Programs (APDOM): Announcements of austerity programs in IIPS countries and Greece.

- ECB- Banks. ECB policy initiatives supporting the banking system. These include the longterm refinancing operation (LTRO) that has been implemented and renewed during our sample period.

- ECB:MP. ECB's monetary policy actions including changes in key interest rates, expansion of swap lines, and Governor Draghi's speech (London, 2012) where he declared that the ECB would do everything possible ("whatever it takes") to preserve the euro.

- ECB: Easing Collateral. ECB policy measures supporting sovereigns, including debt purchases and suspension of programs tightening financial regulation.

- ECB: Tightening Collateral. ECB tightening of collateral constraints, including suspension of government purchase programs or limits eligibility for government debt as collateral.

- ECB: Financial Stability. ECB policies designed to support and improve financial stability, including public and private debt securities markets programs and the Outright Monetary Transactions (OMT) announcements and implementation. ${ }^{8}$

- ECB/EU Joint Initiatives. EFSF and European Stability Mechanism (ESM) programs.

- EU Fiscal Rules. Tightening of fiscal rules and regulations in EU, including proposals, decisions and implementation of the fiscal compact.

- EU Wide Stress Tests. EU wide bank stress test

- Single Supervisory Mechanism (SSM)

\footnotetext{
${ }^{7}$ In addition, Table A.1 in Appendix A lists five additional types of news announcements and four measures of financial instability as control variables in our empirical analysis.

${ }^{8}$ In the period July to September 2012, the Governing Council of the ECB announced that the bank might engage in outright monetary transactions (OMTs) in the secondary markets for government bonds. In particular, on July 26, 2012, during a conference in London, President Draghi said that the ECB was ready to do "whatever it takes" to preserve the euro within the limits of its mandate. On August 2, 2012, during the press conference after the Governing Council meeting, President Draghi announced, “ECB may undertake outright open market operations.” Finally, on September 6, 2012, the ECB's Governing Council announced a number of technical features of the OMT program. More precisely, the ECB stated that no ex ante quantitative limits would be considered for outright transactions in secondary sovereign bond markets, that purchases would concentrate on bonds with remaining maturities of up to three years, and without seniority (pari passu), and that bond purchases would be conditional. The effect of these OMT announcements on European bond yields is investigated by Altavilla et al. (2014). De Grauwe (2013) argues that OMT, by explicitly accepting unconditional lender of last resort responsibility, was a fundamental departure from previous ECB policy.
} 
- Support: Announcement of EU/IMF financial assistance to IIPS governments and Greece.

As our objective is to analyze the effects of news from IIPS and Greece on the four IIPS countries, we code separate categories of austerity plans and bailouts for each of these five countries. For example, coding in this way allows us to analyze the effects of a new austerity plan in Portugal on both the Portuguese CDS spread as well as on the Spanish CDS spread (allowing for potential spillover effects).

Table 3 reports the number of events for each news announcement for the full sample. As expected there is more news on Greece than on other countries, reflecting the severe problems in the Greek economy. On the other hand, for some indicators and countries there are no news announcements at all, e.g. no bailout for Italy.

We have used a conservative interpretation of the events in order not to contaminate our estimates. This limits the number of events but gives confidence that the events are exogenous of contemporaneous financial market fluctuations. We have also excluded news announcements reflecting general market conditions such as the announcement by EU that it endorsed Greece's austerity plan announced on Feb. 3, 2010. Labor strikes are not classified as news even though they may have led to greater uncertainty about the likely implementation or ultimate success of austerity plans.

We use the date of the announcement (as a dummy variable on the day of announcement) and measure the effect on CDS spreads. This follows related event studies on the effects of general policy announcements on financial assets prices (e.g., Dooley and Hutchison, 2009; Ait-Sahalia et al., 2012). However, there is no generally accepted methodology or systemic data source on market expectations of austerity plans or other policy actions. Hence, a result of "no significance," or even an unexpected directional sign, may be due to either the policy being fully expected or disappointing to market participants in that a more forceful policy action was anticipated by the market.

Having defined the categories, we define a dummy variable taking the value one on the date when the news was announced; otherwise the dummy is equal to zero. Such a definition excludes the possibility that some news announcements are anticipated, implying that there is a market reaction prior to the actual announcement. Markets may also not respond immediately to the news announcement but the following day. To address this point, we follow the standard approach in the event-study literature and define our event over a three-day period, i.e. we let the dummy variable be equal to unity on the day of the event, the previous day and the following day. ${ }^{9}$ Using a longer period for the event runs the risk of contaminating our results as other news may also affect our measures. A too narrow event period could imply that we exclude anticipation effects and are not taking into account that the market may not respond immediately.

\footnotetext{
${ }^{9}$ We have also estimated models where the event is constructed as the day of the announcement only, i.e., we have a dummy variable taking the value one on the day of the event and zero otherwise. In general, the sign of the point estimates is unaffected but the standard errors are considerably larger than when using a three-day event period.
} 
Many of the news announcements we study are related to policy initiatives that are discussed in public prior to any decision. The closer to the expected policy decision, the more likely it is that the market anticipates the particular announcement. This is particularly relevant for EU policy initiatives, for example the decisions to establish ESM, where the formal announcement may be anticipated. Distinguishing between anticipated and unanticipated news announcements on policy initiatives is a problem generally in this literature. To partly address this issue, in section 4.3, we focus on a subset of policies that distinguish between announcement and implementation dates.

\subsection{Estimation equations and hypotheses}

We focus on the 2009-01-01 to 2012-09-04 sample using daily data. This period encompasses the global financial crisis which evolved into the European sovereign debt and bank crisis. As stated above, we focus on the IIPS group. There are missing observations in the dataset, resulting in regression samples that are not the same across all countries. Our main empirical methodology is based on dynamic panel regressions of the following type:

$$
\Delta C D S_{i, t}=\alpha+\beta_{0} \Delta C D S_{i, t-1}+\underbrace{\beta_{i} X_{i, t}}_{\text {Domestic austerity }}+\underbrace{\delta_{k} Z_{k, t}}_{\text {Common Policy }}+\sum_{l} \theta_{l} Y_{l, t}+\varepsilon_{i, t}
$$

where $\triangle C D S_{t}$ is the change in the CDS spread in IIPS country $i, X_{i, t}$ denotes domestic austerity announcements in country $i$ and $Z_{k, t}$ denotes (“common") EU and ECB policy initiatives or changes in financial or fiscal regulations (all common news announcements listed in Table 2), and $Y_{l, t}$ contain other controls, i.e., probability of simultaneous default of two or more banks provided by ECB, global risk aversion indicator also provided by ECB, the VIX index and the 10-year Treasury constant maturity rate both downloaded from the St. Louis Federal Reserve Bank FRED databank, see Appendix A. We use the change in these four control variables in our panel data regressions. In addition, we include five types of news announcements in IIPS countries plus Greece (listed in Appendix A). The latter includes foreign austerity programs, e.g. the effect of austerity program in country $\mathrm{j}$ on CDS spreads in country $i$. The effect of news is measured by $\beta_{i}$ for IIPS country austerity plans and by $\delta_{k}$ for the common EU/ECB news announcements. We include the lagged change in the CDS spread to capture dynamics, as in Dooley and Hutchison (2009) and Beetsma, Giuliodori, de Jong and Widijanto (2012).

Fixed effects estimation corrects for group effects that make OLS estimates from a pooled regression inconsistent. However, it is still the case that the demeaned dependent variable in the fixed effects model is correlated with the residuals through the group mean, implying that the residual influences the dependent variable and therefore also the mean for all $t$. Several methods produce consistent estimates of a dynamic panel data, including the difference and system Generalized Methods of Moments (GMM) approach suggested by Arellano and Bond (1991) and Blundell and Bond (1998). Both these methods apply to the case of large $N$ and small $T$ panels, i.e., many individuals and few time periods. The basic idea of these 
methods is to use more instruments and can improve efficiency significantly. A potential problem when implementing the GMM methods is that the number of instruments explodes with $T$, overall the number of instruments is quadratic in $T$. In our empirical application $N \leq 6$ and $T=959$, implying a very large number of instruments. Roodman (2009) discusses many of the potential pitfalls of instrument proliferation and its consequences, including over fitting of endogenous variables, bias in estimates and the weakening of Sargan tests.

These issues have not been fully analyzed in the literature and there exists very little guidance on how to handle this problem in GMM estimation of dynamic panel data models, see the discussions in Hall and Peixe (2003), Roodman (2009) and Bontempi and Mammi (2012). At the same time, we know that as $T \rightarrow \infty$ the bias disappears in the fixed effects model. Given the lack of solid methods and the fact that we have a panel with small $N$ and large $T$ we assume that inefficiency is likely to be small. Hence, we use the fixed effects estimator when analyzing the effects of news announcements.

\section{Empirical Results: Market Responses to Policy Announcements}

\subsection{Preliminaries: Event study}

As part of our preliminary empirical work, we consider the grouped policy news announcements (11 groups) and use a matched sample test to analyze whether there are significant shifts in the CDS spread between the pre-event window, the event period, and the post-event window. The matched sample test compares changes in the CDS spread between the event and the pre- and post-event windows. The pre- and post-event windows are each 3-day periods. For each observation, we compute the difference between the change in the CDS spread before and after the event, compute the mean and standard deviation of the difference. Under the assumption that both samples are normally distributed we use the t-ratio with $n-1$ degrees of freedom where $n$ is the number of paired observations to test whether the difference is significantly different from zero. Using these tests, we can make inferences on the question of whether a particular type of policy announcement has reversed the direction or changed the rate of change in CDS. As is standard in the literature, we compute the cumulative change in the CDS spread.

Table 4 and Figure 4 (Table 5 and Figure 5) report the results for sovereign (bank) CDS spreads. The matched-sample tests indicate that five (five) types of policy announcements resulted in significant changes in sovereign (bank) CDS spreads between the policy announcement event period compared with the preannouncement window. Moreover, nine (six) cases saw significant changes in CDS spreads between the post-announcement window and the pre-announcement window.

Figures 4 and 5 illustrate the substantial changes in CDS spreads for a number of policy announcements. Numerous policy announcements and actions have apparently lowered, or slowed the rise, in CDS spreads 
and restored confidence to markets. Particularly noteworthy for sovereign spreads are easing of ECB collateral constraints (ECBGOV), ECB financial stability policy announcements (ECB: Financial Stability), announcement of the single supervisory mechanism (SSM) and EU-wide bank stress test results (EU Wide Stress Test). For bank CDS spreads, ECBGOV, ECB: Financial Stability and EU Wide Stress Test are particularly important.

These 11 policy categories in most cases represent aggregates of quite diverse policies. In our panel estimates, reported in the next section, we move beyond this preliminary analysis by investigating the market effects of each of the 21 distinct policy announcements and report individually significant responses.

\subsection{Policy effects: Panel regressions}

Table 6 shows the significant results from our panel regressions. These are from the full set of results with 21 event categories and the control variables shown in Appendix B. The results indicate that certain ECB financial stability actions significantly reduced CDS spreads in sovereign (SMP and OMT) and bank (OMT) markets. EU-wide fiscal rules also had the desired effect and significantly lowered CDS spreads in both sovereign (FRSix and FRtwo) and bank bond markets (FRtwo). These measures had the desired impact qualitatively and, especially in the case of the OMT announcements (potentially unlimited support of sovereign markets), were very favorably received by the markets. Specifically, the largest estimated effects on sovereigns were $-16 \mathrm{bp}$ and $-14 \mathrm{bp}$, respectively, for the SMP and OMT announcements and $-25 \mathrm{bp}$ for the Fiscal Two-Pact announcement. ECB monetary actions to relax monetary policy (MP) and to expand its balance sheet to support the banking system (ECBBAL), as well as the SSM announcement, also had the desired effect of significantly reducing sovereign spreads. However, these latter announcements surprisingly did not significantly impact bank CDS spreads. The easing of ECB collateral constraints and stress test announcements, by contrast, significantly raised sovereign spreads but had little contemporaneous effect on bank spreads.

News effects on both sovereign and bank bond CDS prices is especially noteworthy: ECB easing of collateral constraints - focusing on bank liquidity but applying to sovereign bond collateral — only impacted sovereign spreads; the OMT (outright monetary transactions) financial stability announcement focusing on sovereign markets had a large impact on bank CDS spreads (-10 bp); and fiscal rules focusing on sovereign markets but had a surprisingly large impact on bank spreads (-17 for FRtwo). On the other hand, no announcement changed bank CDS spreads without also significantly affecting sovereign spreads.

By contrast, a number of programs are conspicuous by their absence from Table 6. In particular, (a) domestic austerity programs, (b) ECB bank programs (expanding ECB balance sheet, bank recapitalizations), (c) ECB tightening of collateral constraints, (d) ECB/EU joint programs (EFSF, ESM), and (e) "support" (announcements of EU/IMF financial assistance to IIPS governments and Greece) did not 
systematically move CDS spreads for either sovereign debt or bank bonds. Either these programs did not restore confidence in sovereign debt or bank solvency, perhaps viewed by markets as too little or too late in announcement and implementation, or they were fully anticipated. Moreover, austerity programs could affect CDS markets in two ways, with potentially offsetting effects — on the one hand shoring up fiscal sustainability but on the other hand lowering aggregate demand and worsening recessionary conditions.

Comparing the panel and matched sample results for sovereign CDS spreads, the ECB: Financial Stability category (matched sample) is apparently driven by significant negative effects associated with the OMT and SMP announcements (panel results). Similarly, the contemporaneous effect of the bank stress test (EU-Wide Stress Test) is positive and significant in both the panel and matched sample results. For the bank CDS results, the matched sample tests indicate that ECB: Financial Stability significantly reduced spreads. This effect is apparently driven by the OMT program (included in the Financial Stability group), i.e. the panel results indicate a large and significant negative effect (-10.5 basis points).

Returning to the EU Wide Bank Stress tests, the matched sample results indicate a large negative effect between the pre- and post-event windows for both sovereign and bank CDS spreads. (This result is in sharp contrast with the pre-event window and the event period comparison.) To compare the panel results with the matched sample post-event window, we estimated the panel regression with the lagged stress test indicator. We find a strong negative and significant effect (-22.5 basis points) for sovereigns but not for banks (-12.3 basis points but not statistically significant). These results are broadly consistent with the matched sample tests.

\subsection{Announcement versus implementation effects}

In many cases it is difficult to distinguish between market responses to the announcement and implementation of policies. For some policies, however, it is possible to clearly distinguish between announcement of policy programs, announcement of operation details, and implementation. We make these distinctions for six policy interventions: (1) the covered bonds purchasing program (CBPP and CBPP2), (2) Long Term Refinancing Operations (LTRO), (3) the securities market program (SMP), (4) European Financial Stability Facility (EFSF), (5) European Stability Mechanism (ESM), and (6) the Six-Pack/TwoPack fiscal initiatives. Appendix C presents the detailed results on when these programs where announced and implemented.

\subsubsection{Announcement versus implementation timing}

The following three programs were established by the ECB.

Covered Bonds Purchasing Programs: The CBPP was first announced on May 7, 2009 by the ECB. Almost a month later, on June 4, 2009, the ECB announced the operational specifications of the program including when it was scheduled to be implemented. On July 6, 2009 the first round of the program was implemented and lasted until June 30, 2010. A second round of the program (CBPP2) was announced on October 6, 2011. 
The ECB released the operational specification on November 3, 2011 and the program was implemented from November 28, 2011 until October 31, 2012. We distinguish between these dates in the empirical analysis below.

Securities Market Program: The SMP is also an ECB program. This program was announced on May 10, 2010, operational specification was revealed on May 14, 2010 and the program was implemented in two rounds. The first round lasted from May 17, 2010 until July 9, 2010, and the second round lasted from August 16, 2010 until January 16, 2011.

Long-term Refinancing Operations: the LTRO was announced by the ECB on December 8, 2011 and the first round was implemented on December 21, 2011. The press release from the Governing Council of the ECB, made public on December 8, also included details on the operational specification of the program. A second round of LTOR was implemented on February 28, 2012.

The following three programs were proposed by the EU Commission and agreed upon by the European Council, ECOFIN and the EU Parliament.

European Financial Stability Facility: The EFSF was proposed, agreed to and implemented in 2010 as part of the rescue and bail-out of Greece and other countries. The decision to establish this facility was taken on May 9, 2010 and it went into force on June 7, 2010.

European Stability Mechanism: The ESM replaced the EFSF. On October 29, 2010, the European Council agreed to establish a crisis management mechanism in the euro area to replace the EFSF and the Greek loan facility. On December 17, 2010, a political agreement was reached to establish the ESM and it was agreed to add a paragraph to the Treaty using a simplified process in order to have legal support for the establishment. The European Council adopted a package including ESM on March 25, 2011. On July 11, ECOFIN confirmed the establishment of the ESM. Prior to implementation, two modifications were made to the ESM (July 21 and December 9, 2011). Finally, the addition to the Treaty was signed on February 2, 2012 and ESM went into force on September 27, 2012. The ESM board of governors held their inaugural meeting on October 8, 2012.

Fiscal Six-Pack: The Six-Pack emerged from a EU Commission/European Council task force proposal on how to strengthen the fiscal framework in Europe, including the Macroeconomic Imbalance Procedure. On March 25, 2010, ECON and the EU Commission reached an agreement to move forward and start negotiations with the EU Parliament. The decision to adopt the Six-Pack program was made on November 8, 2011 and went into force on December 13, 2011.

Looking more closely at the dates when different policy initiatives were announced, we find three overlapping dates: the first operational specification of ESM was revealed at the same time as the second announcement of the Six-Pack; LTRO was announced at the same time as the operational specifications were stated; and the operational specification of the EFSF was stated at the same time as the SMP was 
announced. In the empirical analysis we have included these events but results are not reported since we cannot distinguish between the effects of these announcements.

\subsubsection{Announcement versus implementation results}

Table 7 reports the effects of these programs by stage - initial announcement, operational specification announcement and implementation — on sovereign CDS spreads. ${ }^{10}$ As above, we use a three-day window and define a dummy variable equal to one the day prior to the event day, the day of the event and the day after the event day. This applies to all stages, the initial announcement (and any further revisions of the initial announcement), the day the operational specifics were announced (and possibly revised) and the implementation (and for different implementation rounds).

The results vary markedly by the type of program and the stage. Of the three ECB programs - CBPP, LTRO and SMP - only the initial SMP program announcement was received (very) favorably by the markets, reducing sovereign CDS spreads immediately and over a longer-period by 32 to 38 basis points. But the subsequent announcement over operational specification and actual implementation (second round) apparently disappointed market participants and spreads increased somewhat (7-8 basis points). Although we found no impact effect for either CBPP or CBPP2 upon the initial announcement, both programs significantly reduced spreads when operational details were released (CBPP and CBPP1) or at implementation (CBPP1). Markets reacted unfavorably however, over the LTRO program and, in the second round, CDS spreads rose significantly (20 basis points).

In terms of the EC programs, implementation of the EFSF had a substantial stabilizing impact, reducing spreads 11-13 basis points (short- and long-term). The ESM apparently disappointed markets at announcement (spreads rose 9-10 basis points) and also at the stages of European Council agreement and confirmation (increasing spreads). The first revision in the ESM, however, helped restore market confidence, lowering (long-term) spreads by about 43 basis points. However, the second revision, and when the Treaty was signed, did not move market spreads. The Six-Pack fiscal program had a modest but significant impact (long-term at -4 basis points) but operational details and implementation apparently disappointed markets and were associated with small increases in CDS spreads.

\subsection{EU news announcements on other small EU countries outside the crisis center}

IIPS countries were at the heart of the sovereign debt crisis and many of the EU and ECB policies were directed to stabilize their economies and markets. In this section, we investigate to what extent small EU countries outside the center of the crisis were affected by the EU/ECB policy announcements. To this end, and analogous to our previous panel regressions, we consider the effect of these policy announcements on

\footnotetext{
${ }^{10}$ We have also estimated regressions testing whether these announcements affect banks CDS spreads. We do not find evidence suggesting significant effects. These results are not reported here for brevity but are available upon request from the authors. It seems as if these announcements are of significance, they mainly affect sovereign CDS spreads.
} 
sovereign CDS spreads in six small EU countries, three EMU members (Cyprus, Malta, and Slovak Republic) and three non-EMU members (Czech Republic, Hungary and Romania). The estimating equation uses identical explanatory variables as for the IIPS estimations. We report the results in Table 8. In this panel regression we also allow for different responses between the EMU and non-EMU countries. We report in the table coefficients and standard errors representing the total impact effect for each group (not marginal effects).

The overall picture suggests that many EU and ECB policy announcements had significant impacts, particularly on non-EMU countries. Nine (four) policy announcement types were significant in the nonEMU (EMU) group. However, most of the significant policy announcements are quite different between these countries and our IIPS group, and even amongst themselves. Three (one) of the significant responses in the non-EMU group (EMU group) coincided with the significant results in the IIPS regressions. In all but one of the "coincident" cases, however, the estimated magnitudes of the responses are much less. Not surprisingly, countries outside of the eye of the crisis responded much less to policy announcements than those at the center-the policies were in large part designed to stabilize the IIPS countries and Greece at the center of the crisis.

\section{Conclusions and further perspectives}

This paper considers the impact of European policy announcements on perceptions of sovereign and bank default risk in four countries greatly affected by the European debt crisis - Portugal, Ireland, Spain and Italy. We distinguish between 21 different types of national, ECB and EU-wide policy announcements, e.g. the implementation of domestic austerity programs, changes in monetary policy, other policy initiatives at the EU level, tightening of fiscal rules, and financial regulation changes. We measure policy announcement effects on sovereign and bank credit default swap spreads, identifying which policies were most effective in quelling market fears during the crisis and whether policy announcements focused on sovereign debt markets affected banks and vice versa. Our primary empirical methodology is dynamic panel regressions using daily data.

We identify several policy announcements which played a large role in immediately dampening market fears for both sovereign and bank risks. For sovereigns, ECB policies at monetary easing (reductions in interest rates), policies aimed at improving financial stability (Securities Market Program and Outright Monetary Transaction program), and fiscal sustainability program announcements (the Two-Pack and the Six Pack programs) lowered CDS spreads. The Outright Monetary Transactions program and the fiscal Two Pack also lowered bank CDS spreads. On the other hand, EU-wide bank stress test announcements initially raised risk perceptions in sovereign markets which were later reversed during the following days. In distinguishing between market impacts of the initial announcement and later implementation of policies, the sharpest result is that announcement of the Securities Market Program initially lowered sovereign CDS spreads substantially but subsequently raised spreads when the program was implemented. By contrast, 
announcement of the second Covered Bond Purchasing Program had little effect on sovereign spreads but when operational specifications of the program were released spreads declined significantly.

These results highlight that a number of programs initially stabilized sovereign and bank bond markets and that announcement and implementation impacts on markets differed in some cases. The results also shed light on how policies designed to stabilize sovereign markets, e.g. fiscal sustainability programs, also impacted risk perceptions in bank bond markets. And policies designed to ensure safety and soundness of the European banking system, e.g. bank stress test, significantly impacted sovereign debt markets. Finally, we also find that a number of policies designed to stabilize markets such as the first Covered Market Bond Program had little immediate impact on either sovereign or bank bond market risk assessments. 


\section{References}

Alfonso, A., D. Furceri and P. Gomes (2012), "Sovereign Credit Ratings and Financial Markets Linkages: Application to European Data", Journal of International Money and Finance, 31(3): 606-638.

Aizenman, J., M. Hutchison and Y. Jinjarak (2012), "What is the Risk of European Sovereign Debt Defaults? Fiscal Space, CDS Spreads and Market Pricing of Risk", forthcoming in Journal of International Money and Finance.

Altavilla, C., D. Giannone and M. Lenza (2016), "The financial and macroeconomic effects of OMT announcements", International Journal of Central Banking, 12(3): 29-57.

Alter, A. and A. Beyer (2012), "The Dynamics of Spillover Effects during the European Sovereign Debt Turmoil", CFS Working Paper No 2012/13.

Arellano, M. and S.R. Bond (1991), "Some Tests of Specification for Panel Data: Monte Carlo Evidence and an Application to Employment Equations", Review of Economic Studies, 58: 277-297.

Aït-Sahalia, Y., J. Andritzky, A. Jobst, S. Nowak and N. Tamirisa (2012), "Market response to policy initiatives during the global financial crisis", Journal of International Economics 87: 162-177.

Beetsma, R., F. de Jong, M. Giuliodori and D. Widijanto (2012), "Spread the News: How the Crisis Affected the Impact of News on the European Sovereign Bond Markets", CEPR Discussion Papers 9043.

Blundell, R.W. and S.R. Bond (1998), "Initial Conditions and Moment Restrictions in Dynamic Panel Data Models", Journal of Econometrics, 87: 115-143.

Bontempi, M.E. and I. Mammi (2012), "A Strategy to Reduce the Count of Moment Conditions in Panel Data GMM", MPRA Paper No. 40720.

De Grauwe, P. (2013), "The European Central Bank as Lender of Last Resort in the Government Bond Markets", CESifo Economic Studies, 59:520-535.

Dooley, M. and M. M. Hutchison (2009), "Transmission of the U.S. Subprime Crisis to Emerging Markets: Evidence on the Decoupling-Recoupling Hypothesis", Journal of International Money and Finance, 28: 1331-1349.

European Commission (2012), "Quarterly Report on the Euro Area", Economic and Financial Affairs, Vol. 11, No. 4, December 2012, 31-38.

Feld, L., A. Kalb, M.D. Moessinger and S. Osterloh (2017), "Sovereign bond market reactions to no-bailout clauses and fiscal rules - The Swiss experience", Journal of International Money and Finance, 70: 319-343.

Hall A.R. and F.P.M. Peixe (2003), "A Consistent Method for the Selection of Relevant Instruments", Econometric Reviews, 22: 269-287.

Gerlach-Kristen, P. (2015), “The impact of ECB crisis measures on euro-area CDS spreads," Financial Markets and Portfolio Management, 29: 149-168.

Grammatikosa, T., T. Lehnert and Y. Otsubo (2015), "Market perceptions of US and European policy actions around the subprime crisis", Journal of International Financial Markets, Institutions \& Money, 27: 99-113.

International Organization of Securities Commissions (2012), "The Credit Default Swap Market," Report of the Board of IOSCO, FR05/12.

Klomp, J. (2013), “Government interventions and default risk: Does one size fit all?”, Journal of Financial Stability, 9: 641-653.

Markman, H. and J. Zietz (2017), "Determining the Effectiveness of the Eurosystem's Covered Bond Purchase Programs on Secondary Markets", Quarterly Review of Economics and Finance forthcoming. 

335.

Ricci, O. (2015), "The impact of monetary policy announcements on the stock price of large European banks during the financial crisis", Journal of Banking \& Finance, 52: 245-255.

Roodman, D.M. (2009), "A Note on the Theme of Too Many Instruments", Oxford Bulletin of Economics and Statistics, 71:135-158.

Thornton, J. and C. Vasilakis (2017), "The impact of fiscal rules on sovereign risk premia: International evidence", Finance Research Letters, 20: 63-67. 
Table 1: Granger non-causality tests between changes in sovereign and bank CDS spreads in IIPS countries.

\begin{tabular}{|c|c|c|c|c|c|c|c|c|c|c|c|}
\hline \multicolumn{12}{|c|}{ Panel A: Granger non-causality tests } \\
\hline & & \multicolumn{4}{|c|}{ Ireland } & \multicolumn{2}{|l|}{ Portugal } & \multicolumn{2}{|l|}{ Spain } & \multicolumn{2}{|l|}{ Italy } \\
\hline & & \multicolumn{2}{|c|}{ Allied Irish Bank } & \multicolumn{2}{|c|}{ Bank of Ireland } & \multicolumn{2}{|c|}{ Banco Com Portugues } & \multicolumn{2}{|c|}{ Banco de Sabadell } & \multicolumn{2}{|c|}{ Intesa Sanpaolo } \\
\hline & & IRE CDS & Bank CDS & IRE CDS & Bank CDS & PT CDS & Bank CDS & SP CDS & Bank CDS & IT CDS & Bank CDS \\
\hline \multirow[t]{2}{*}{ CDS lags } & F-stat & & $4.90^{* * *}$ & & $2.29 *$ & & $13.85^{* * *}$ & & $31.57 * * *$ & & $15.18 * * *$ \\
\hline & Prob & & 0.008 & & 0.10 & & 0.000 & 0.000 & 0.000 & & 0.000 \\
\hline \multirow[t]{2}{*}{ Bank Lags } & F-stat & 1.27 & & $2.77 *$ & & $3.49 * *$ & & $6.25^{* * *}$ & & $7.04 * * *$ & \\
\hline & Prob & 0.282 & & 0.063 & & 0.031 & & 0.002 & & 0.001 & \\
\hline \multicolumn{12}{|c|}{ Panel B: Contemporaneous correlations } \\
\hline \multicolumn{2}{|l|}{ Correlation } & \multicolumn{2}{|l|}{$0.26 * * *$} & \multicolumn{2}{|l|}{0.04} & \multicolumn{2}{|l|}{$0.44 * * *$} & \multicolumn{2}{|l|}{$0.37 * * *$} & \multicolumn{2}{|l|}{$0.75^{* * *}$} \\
\hline \multicolumn{2}{|l|}{ t-stat } & \multicolumn{2}{|l|}{6.48} & \multicolumn{2}{|l|}{1.06} & \multicolumn{2}{|l|}{15.25} & \multicolumn{2}{|l|}{12.54} & \multicolumn{2}{|l|}{35.73} \\
\hline \multicolumn{2}{|l|}{ Probability } & \multicolumn{2}{|l|}{0.00} & \multicolumn{2}{|l|}{0.29} & \multicolumn{2}{|l|}{0.00} & \multicolumn{2}{|l|}{0.00} & \multicolumn{2}{|l|}{0.00} \\
\hline \multicolumn{2}{|l|}{ Samples } & \multicolumn{2}{|c|}{ 1/02/2009- 4/21/2011 } & \multicolumn{2}{|c|}{$1 / 01 / 2009-2 / 22 / 2012$} & \multicolumn{2}{|c|}{$1 / 02 / 2009-9 / 13 / 2012$} & \multicolumn{2}{|c|}{ 1/05/2009- $9 / 13 / 2012$} & \multicolumn{2}{|c|}{ 1/02/2009- $9 / 13 / 2012$} \\
\hline
\end{tabular}

Note: Panel A reports tests of the null hypothesis of no Granger causality between changes in sovereign and bank CDS spreads for each IIPS country. Panel B reports estimates of the contemporaneous correlation between changes in sovereign and bank CDS spreads. 


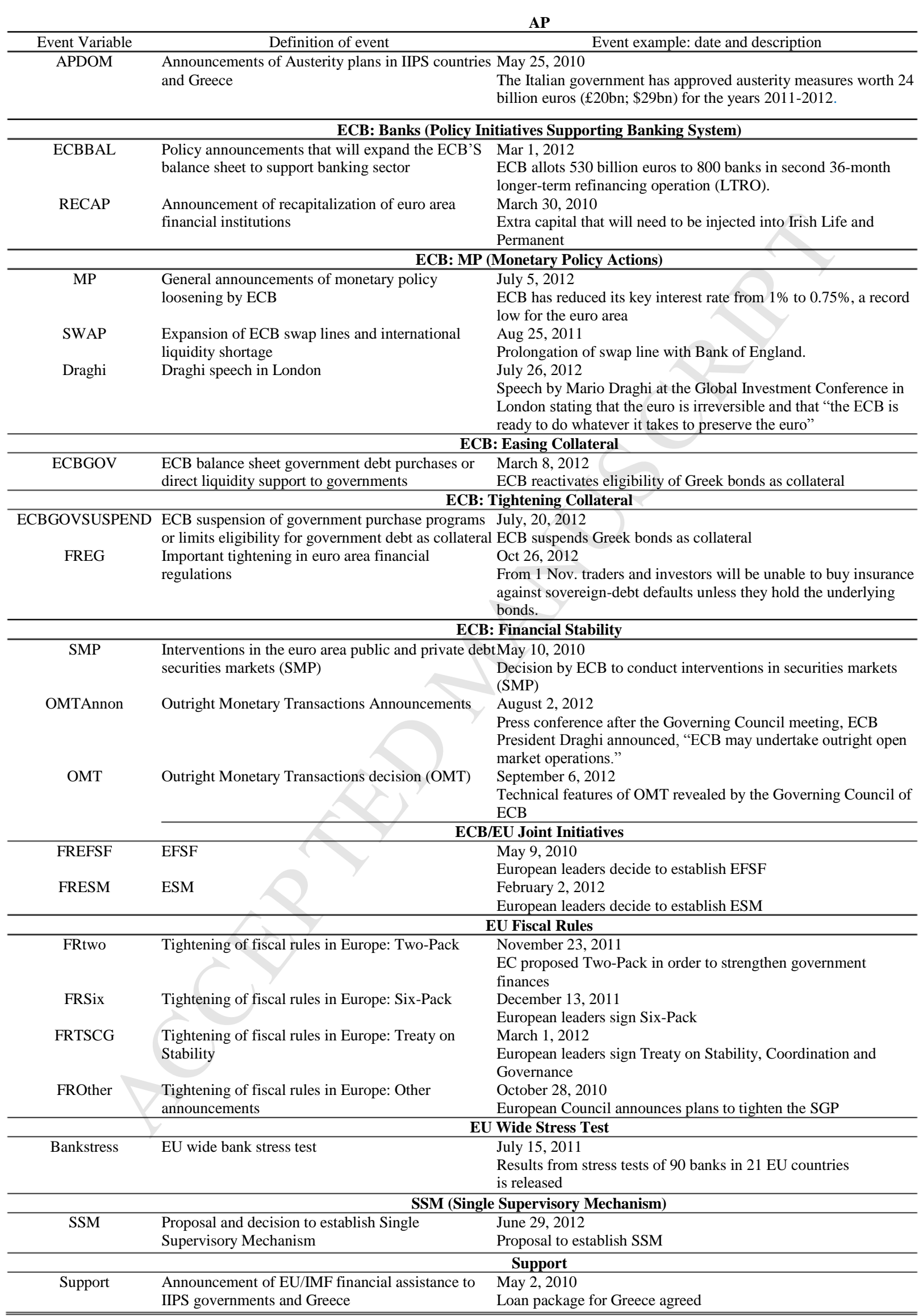


Table 3: News Announcements: IIPS, Greece and ECB/EU.

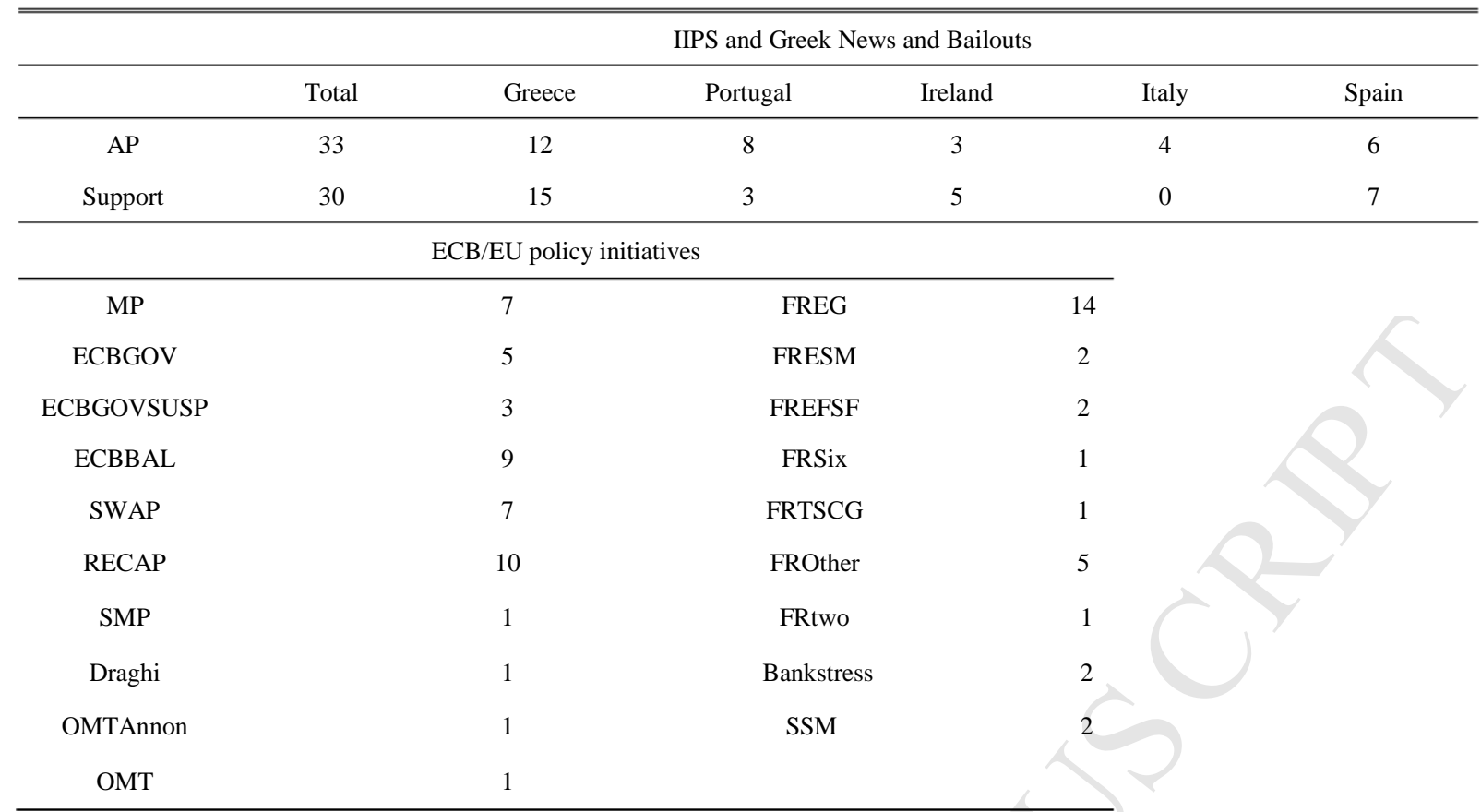

$\overline{\mathrm{AP}}=$ austerity programs; Support=EU/IMF financial assistance; $\mathrm{MP}=$ monetary easing; ECBGOV=ECB government debt purchases or direct liquidity support; ECBGOVSUSP=ECB suspension of debt purchase programs; ECBBAL=ECB support of banks; SW=ECVB swap lines; RECAP=recapitalization of Euro financial institutions; ECBSMP=Securities market program; Draghi=speech by Mario Draghi; OMTAnonn=Outright monetary transaction announced; OMT=OMT initiated; FREG=tightening of financial regulations in Euro area; FRESM=tightening fiscal rules: ESM; FREFSF=tightening of fiscal rules: EFSF; FRtwo=tightening of fiscal rules: Two-Pack; SSM=Single Supervisory Mechanism; Bankstress=EU wide stress test; FRSix=Tightening of fiscal rules: Six-Pack; FRTSCG=tightening of fiscal rules: Treaty on Stability, Coordination and Governance in the Economic and Monetary Union; FROther=other tightening of fiscal rules. 
Table 4: Matched sample tests of changes in sovereign CDS spreads in IIPS countries in pre-event window, during the event and post-event window.

\begin{tabular}{lcccccc}
\hline \hline & Pre-event & Event & Post-event & H0: Pre-event=Event & H0: Pre-event=Post-event & H0: Event=Post-event \\
\hline AP & 20.06 & -14.12 & 5.98 & 0.000 & 0.000 & 0.000 \\
ECB: Banks & 0.12 & 5.12 & 4.78 & 0.106 & 0.892 & 0.166 \\
ECB: MP & 20.54 & -15.37 & 2.68 & 0.000 & 0.000 & 0.000 \\
ECB: Easing Collateral & 29.29 & -30.19 & 3.60 & 0.000 & 0.000 & 0.000 \\
ECB: Tightening Collateral & 6.68 & -15.90 & 9.35 & 0.000 & 0.029 & 0.317 \\
ECB: Financial Stability & -9.29 & -30.25 & -7.86 & 0.210 & 0.099 & 0.877 \\
ECB/EU Joint Initiatives & 8.51 & -1.69 & -17.56 & 0.427 & 0.047 & 0.001 \\
EU Fiscal Rules & 4.51 & -1.58 & 8.70 & 0.163 & 0.002 & 0.198 \\
EU Wide Stress Test & 33.26 & 21.98 & -55.43 & 0.156 & 0.219 & 0.000 \\
SSM & 15.55 & -37.27 & 4.42 & 0.000 & 0.000 & 0.004 \\
Support & -4.01 & -4.33 & 13.23 & 0.904 & 0.001 \\
\hline \hline
\end{tabular}

Note: Pre-event, Event and Post-event show the cumulative change in CDS spreads in pre-event window, during the event and postevent window. A three days' window is used. The p-values of matched sample (paired comparison) tests of changes in cumulative CDS spread changes are shown in the last three columns. Underlying assumption is that both series are normally distributed.

Table 5: Matched sample tests of changes in bank CDS spreads in IIPS countries in pre-event window, during the event and post-event window.

\begin{tabular}{lcccccc}
\hline \hline & Pre-event & Event & Post-event & H0: Pre-event=Event & H0: Pre-event=Post-event & H0: Event=Post-event \\
\hline AP & 21.09 & 2.10 & 9.72 & 0.004 & 0.000 & 0.070 \\
ECB: Banks & -5.04 & -6.69 & 6.43 & 0.797 & 0.037 & 0.002 \\
ECB: MP & 14.10 & 2.10 & -3.06 & 0.045 & 0.395 & 0.001 \\
ECB: Easing Collateral & 25.89 & -16.97 & -9.52 & 0.000 & 0.175 & 0.000 \\
ECB: Tightening Collateral & 8.36 & 4.63 & 11.47 & 0.618 & 0.305 & 0.570 \\
ECB: Financial Stability & 2.73 & -18.38 & -20.71 & 0.114 & 0.739 & 0.039 \\
ECB/EU Joint Initiatives & 13.14 & 28.04 & 0.54 & 0.301 & 0.019 & 0.081 \\
EU Fiscal Rules & 0.86 & 2.92 & 8.26 & 0.540 & 0.322 & 0.126 \\
EU Wide Stress Test & 15.15 & 6.99 & -37.34 & 0.060 & 0.007 & 0.001 \\
SSM & 10.10 & -29.09 & -8.96 & 0.073 & 0.052 & 0.349 \\
Support & -12.74 & -5.02 & 7.61 & 0.127 & 0.003 & 0.001 \\
\hline
\end{tabular}

Note: Pre-event, Event and Post-event show the cumulative change in CDS spreads in pre-event window, during the event and post-event window. A three days' window is used. The p-values of matched sample (paired comparison) tests of changes in cumulative CDS spread changes are shown in the last three columns. Underlying assumption is that both series are normally distributed. 
Table 6: Effects of news announcements on IIPS countries, sovereigns and banks. Fixed effects panel data regression.

\begin{tabular}{|c|c|c|c|c|}
\hline & \multicolumn{2}{|c|}{ Sovereigns } & \multicolumn{2}{|c|}{ Banks } \\
\hline & Short-run & Long-run & Short-run & Long-run \\
\hline ECBBAL & $\begin{array}{l}3.40 * * \\
(0.69)\end{array}$ & $\begin{array}{l}4.08 * * * \\
(0.92)\end{array}$ & & \\
\hline MP & $\begin{array}{l}-2.37 * \\
(0.95)\end{array}$ & $\begin{array}{l}-2.84 * * \\
(1.30)\end{array}$ & & \\
\hline SMP & $\begin{array}{l}-15.66 * * \\
(4.41)\end{array}$ & $\begin{array}{l}-18.75^{* * * *} \\
(6.21)\end{array}$ & & \\
\hline OMT & $\begin{array}{l}-13.98^{*} \\
(4.53)\end{array}$ & $\begin{array}{l}-16.74 * * * \\
(4.50)\end{array}$ & $\begin{array}{l}-10.49 * \\
(3.48)\end{array}$ & $\begin{array}{l}-11.02 * * * \\
(3.48)\end{array}$ \\
\hline FRtwo & $\begin{array}{l}-24.89 * * \\
(4.92)\end{array}$ & $\begin{array}{l}-29.80 * * * \\
(7.56)\end{array}$ & $\begin{array}{l}-17.20 * * \\
(5.23)\end{array}$ & $\begin{array}{l}-18.08 * * * \\
(5.27)\end{array}$ \\
\hline FRSix & $\begin{array}{l}-3.74^{*} \\
(1.30)\end{array}$ & $\begin{array}{l}-4.47 * * \\
(1.78)\end{array}$ & & \\
\hline EU Wide Stress Test & $\begin{array}{l}9.22 * * \\
(2.66)\end{array}$ & $\begin{array}{l}11.04 * * * \\
(3.77)\end{array}$ & & \\
\hline \#countries & 4 & & 4 & \\
\hline Observations & 3552 & & 3164 & \\
\hline $\mathrm{R}^{2}$ & 0.40 & & 0.19 & \\
\hline F-test & $62.24 * * *$ & & 19.90 *** & \\
\hline
\end{tabular}

Note: The table shows the significant estimated parameters in Table B.1 in Appendix B. The long-run effect is calculated as the coefficient divided by one minus the coefficient associated with the lagged CDS spread. Standard errors shown in parentheses below each estimate are clustered and robust. F-test refers to the null hypothesis that all regressors are equal to zero. 


\section{ACCEPTED MANUSCRIPT}

Table 7: Short- and long-run effects of announcement, operational specification and implementation of specific policy initiatives on sovereign CDS spreads. Fixed effects panel data regression.

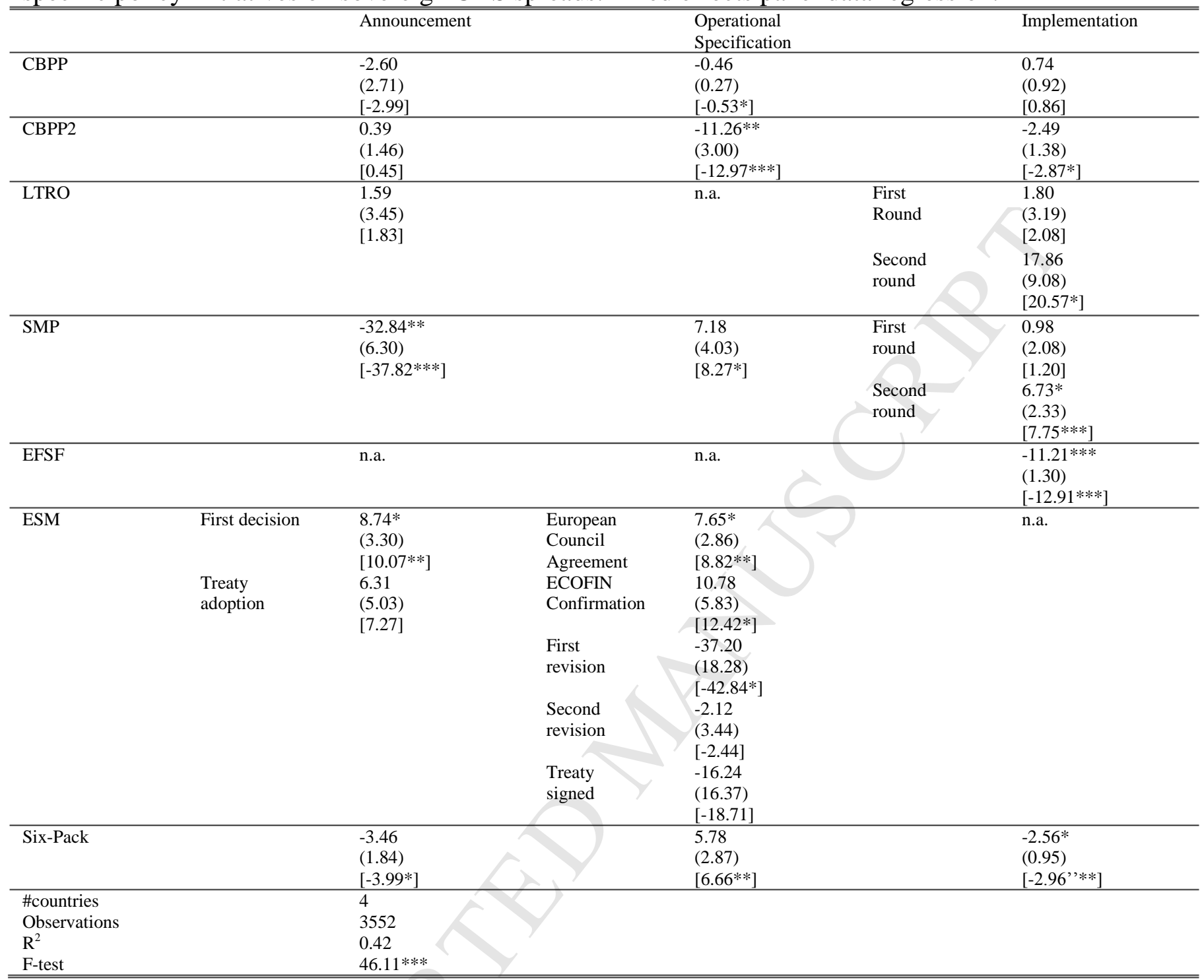

Note: The table shows short-run effects and long-run effects (within brackets) of each policy intervention. The long-run effect is calculated as the coefficient divided by one minus the coefficient associated with the lagged CDS spread. Robust standard errors are shown within parenthesis below each estimate. Some policy initiatives were revised after first announcement or during the process leading to the final operational specification, see Table C.1 in Appendix C. The regression includes all control variables as well as all other policy initiatives used in Table 6. F-test refers to the null hypothesis that all regressors are equal to zero. CBPP $(\mathrm{CBPP} 2)=$ covered bonds purchasing program, round 1 (round 2); LTRO = long-term refinancing operation; SMP = securities market program; EFSF = European financial stability facility; ESM = European stability mechanism. 


\section{ACCEPTED MANUSCRIPT}

Table 8: Impact effect of news announcements on other small EU countries inside (Cyprus, Slovenia, and Slovak Republic) and outside (Czech Republic, Hungary and Romania) EMU.

Fixed effects panel data regression.

\begin{tabular}{|c|c|c|c|c|}
\hline & \multicolumn{2}{|c|}{ non-EMU } & \multicolumn{2}{|c|}{ EMU } \\
\hline & Short-run & Long-run & Short-run & Long-run \\
\hline APDOM & $\begin{array}{c}-1.23 * \\
(0.52)\end{array}$ & $\begin{array}{c}-1.35^{* *} \\
(0.58)\end{array}$ & & \\
\hline RECAP & & & $\begin{array}{c}-1.58^{* * *} \\
(0.40)\end{array}$ & $\begin{array}{c}-1.74 * * * \\
(0.44)\end{array}$ \\
\hline MP & $\begin{array}{c}-3.23 * * \\
(0.82)\end{array}$ & $\begin{array}{c}-3.55 * * * \\
(0.93)\end{array}$ & & \\
\hline SWAP & $\begin{array}{l}1.61 * * \\
(0.62)\end{array}$ & $\begin{array}{c}1.77 * * \\
(0.73)\end{array}$ & & \\
\hline ECBGOVSUSP & $\begin{array}{c}1.87^{*} \\
(0.83)\end{array}$ & $\begin{array}{c}2.06^{* *} \\
(0.93)\end{array}$ & & \\
\hline SMP & $\begin{array}{c}-6.50 * * * \\
(1.34)\end{array}$ & $\begin{array}{c}-7.14 * * * \\
(1.59)\end{array}$ & $\begin{array}{c}-3.60 * * \\
(1.40)\end{array}$ & $\begin{array}{c}-3.96^{* *} \\
(1.60)\end{array}$ \\
\hline OMTAnnon & & & $\begin{array}{l}4.49 * \\
(2.06)\end{array}$ & $\begin{array}{l}4.93 * * \\
(2.26)\end{array}$ \\
\hline FREFSF & $\begin{array}{c}10.22 * * \\
(3.75)\end{array}$ & $\begin{array}{c}11.24 * * * \\
(4.14)\end{array}$ & & \\
\hline FRTSCG & $\begin{array}{c}-4.30 * * \\
(1.21)\end{array}$ & $\begin{array}{c}-4.73 * * * \\
(1.34)\end{array}$ & & \\
\hline FROther & $\begin{array}{c}-5.85 * * * \\
(1.00)\end{array}$ & $\begin{array}{c}-6.44 * * * \\
(1.14)\end{array}$ & & \\
\hline EU Wide Stress Test & $\begin{array}{l}1.85^{*} \\
(0.84)\end{array}$ & $\begin{array}{c}2.04 * * \\
(0.90)\end{array}$ & & \\
\hline Support & & & $\begin{array}{c}-0.12 * * \\
(0.04) \\
\end{array}$ & $\begin{array}{c}-0.14 * * * \\
(0.05) \\
\end{array}$ \\
\hline \#countries & 6 & & $\mathrm{z}_{2}$ & \\
\hline $\begin{array}{l}\text { Observations } \\
\mathrm{R}^{2} \\
\text { F-test }\end{array}$ & $\begin{array}{c}5323 \\
0.14 \\
1483 * * *\end{array}$ & & & \\
\hline F-test & $14.83 * * *$ & & & \\
\hline
\end{tabular}

Note: EU countries: Czech Republic, Hungary and Romania; EMU countries: Cyprus, Slovenia, Slovak Republic. The longrun effect is calculated as the coefficient divided by one minus the coefficient associated with the lagged CDS spread. Standard errors shown in parentheses below each estimate are clustered and robust. The regression includes all control variables as well as all other policy initiatives used in Table 6. F-test refers to the null hypothesis that all regressors are equal to zero. 
Figure 1: CDS spreads in EMU countries 2001-2012.

ACCEPTED $\mathrm{NANUSCRIPT}$
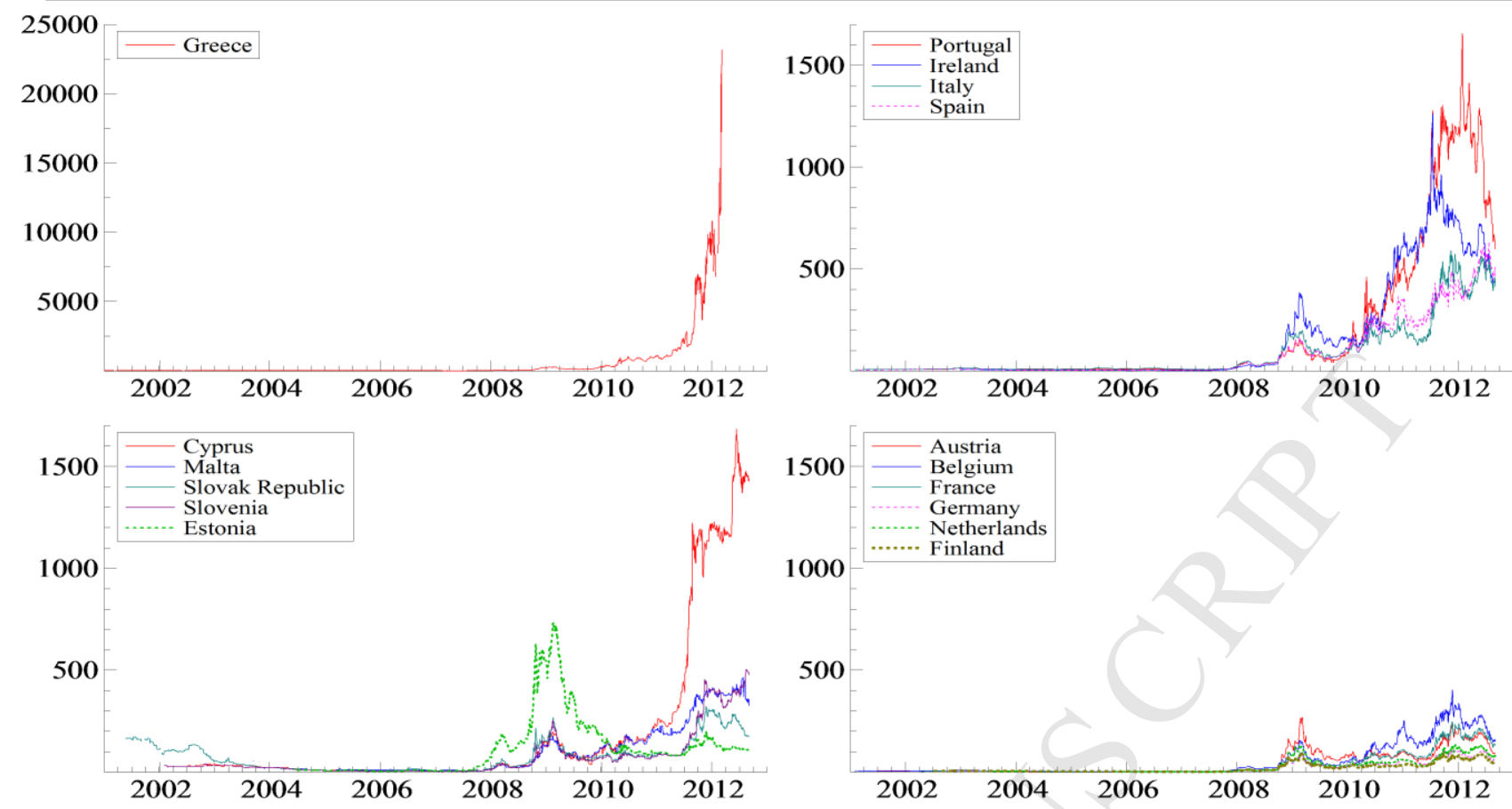

Figure 2: CDS spreads in EU countries not participating in EMU.
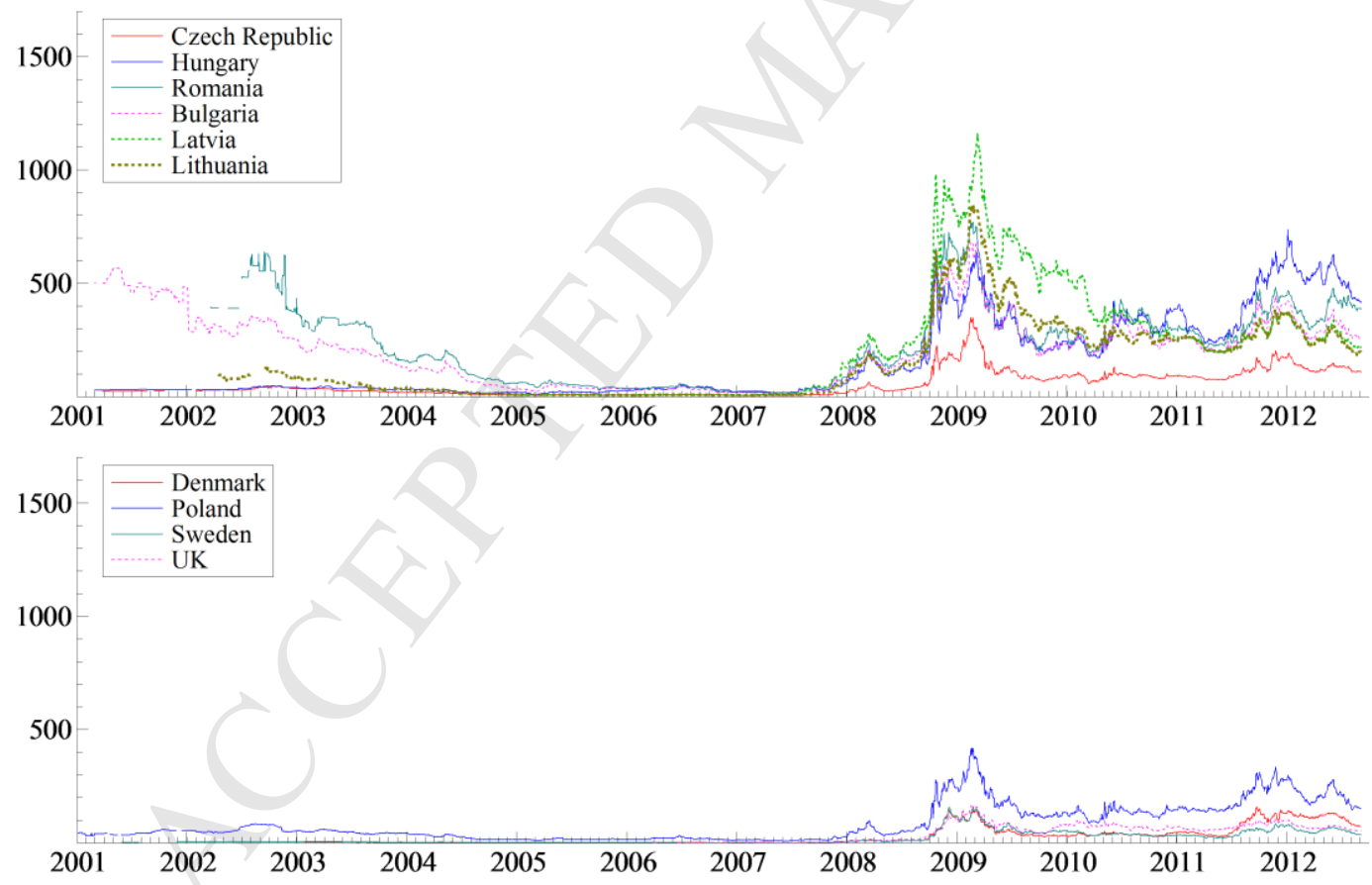
Figure 3: CDS spreads in Spain and Ireland with Fitch Rating downgrading of both sovereign and large banks.
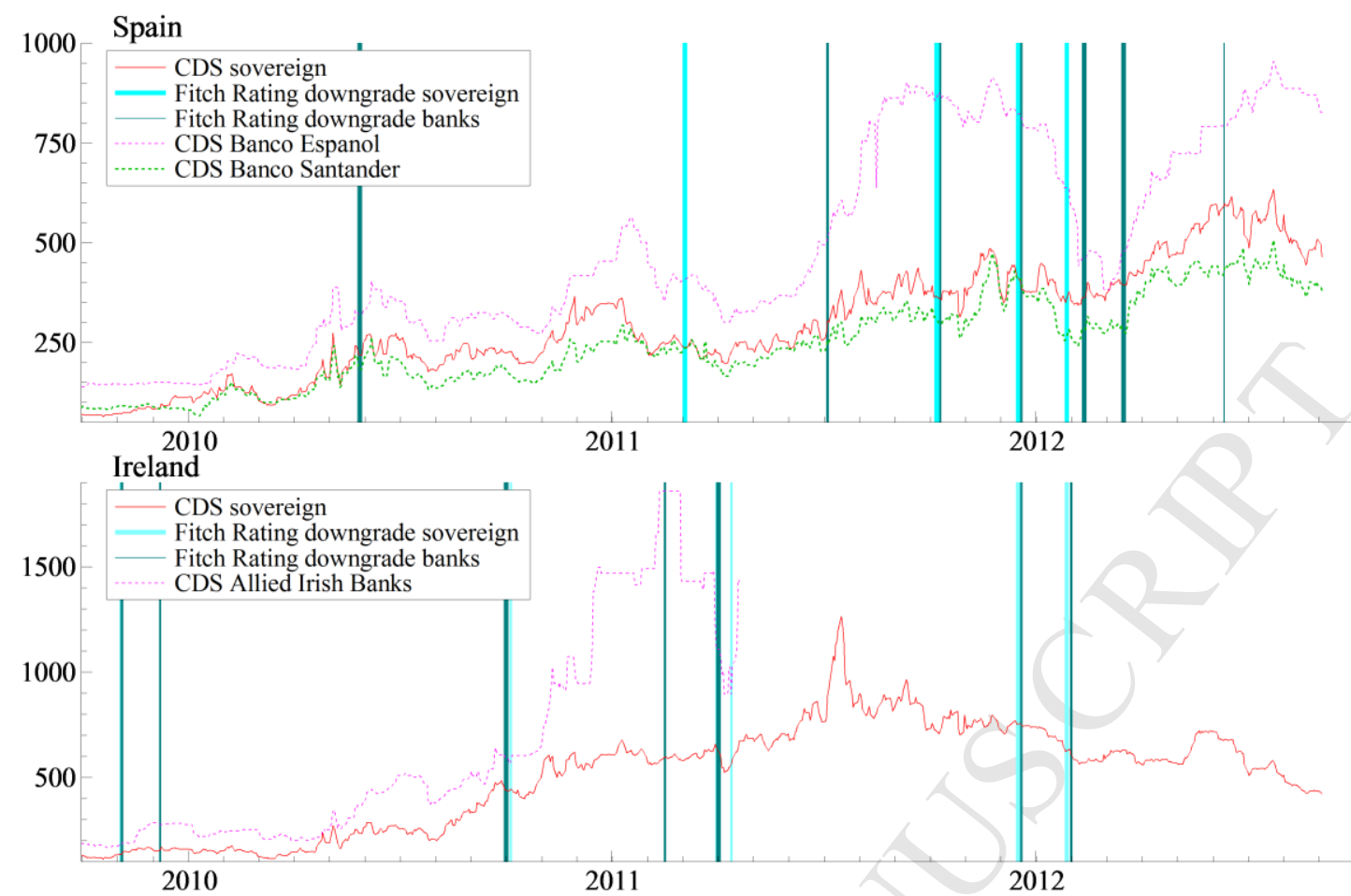

Figure 4: Sovereign CDS spread change prior to, during and after events.

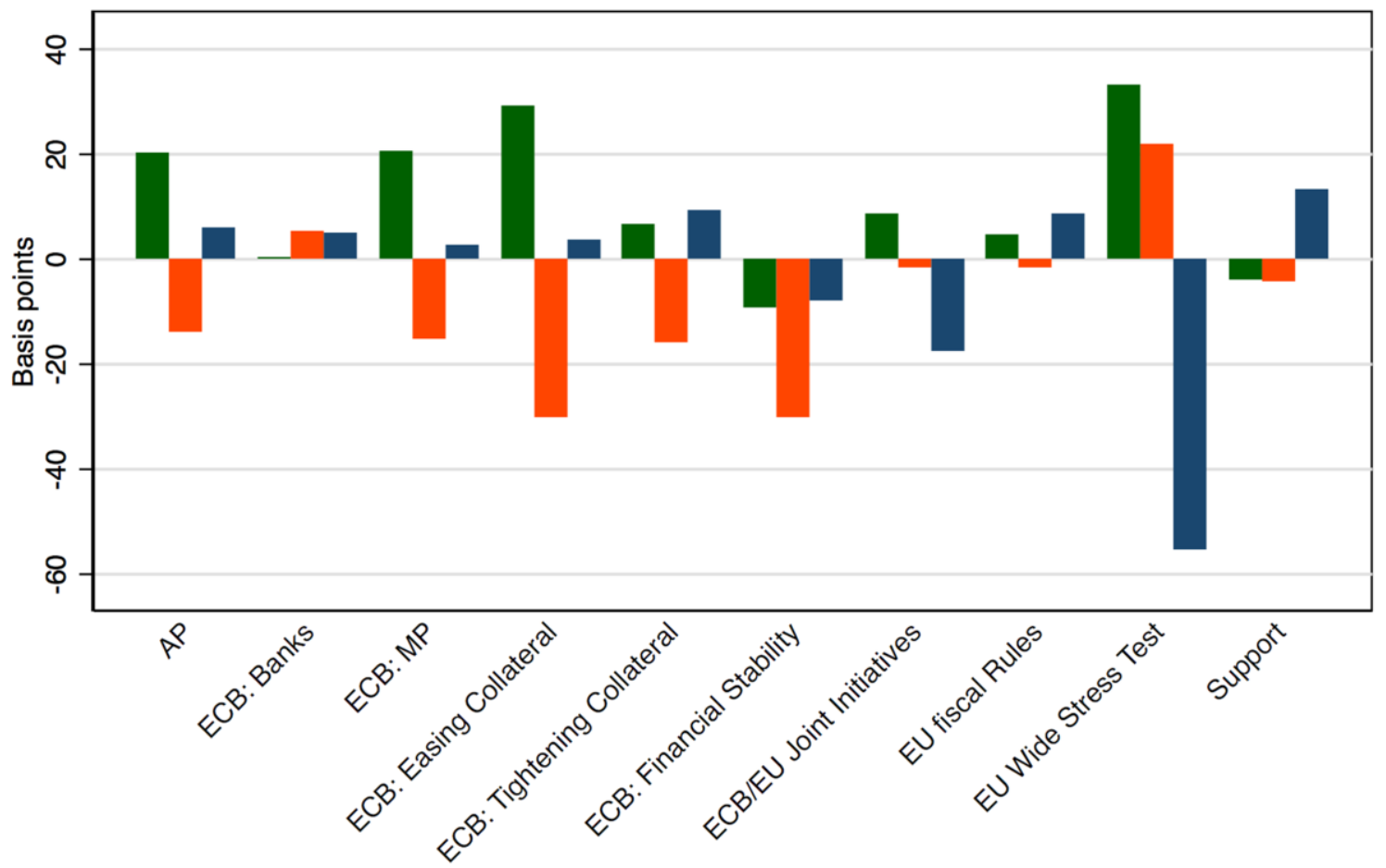
Pre-event
Event
Post-event 
Figure 5: Bank CDS spread change prior to, during and after events.

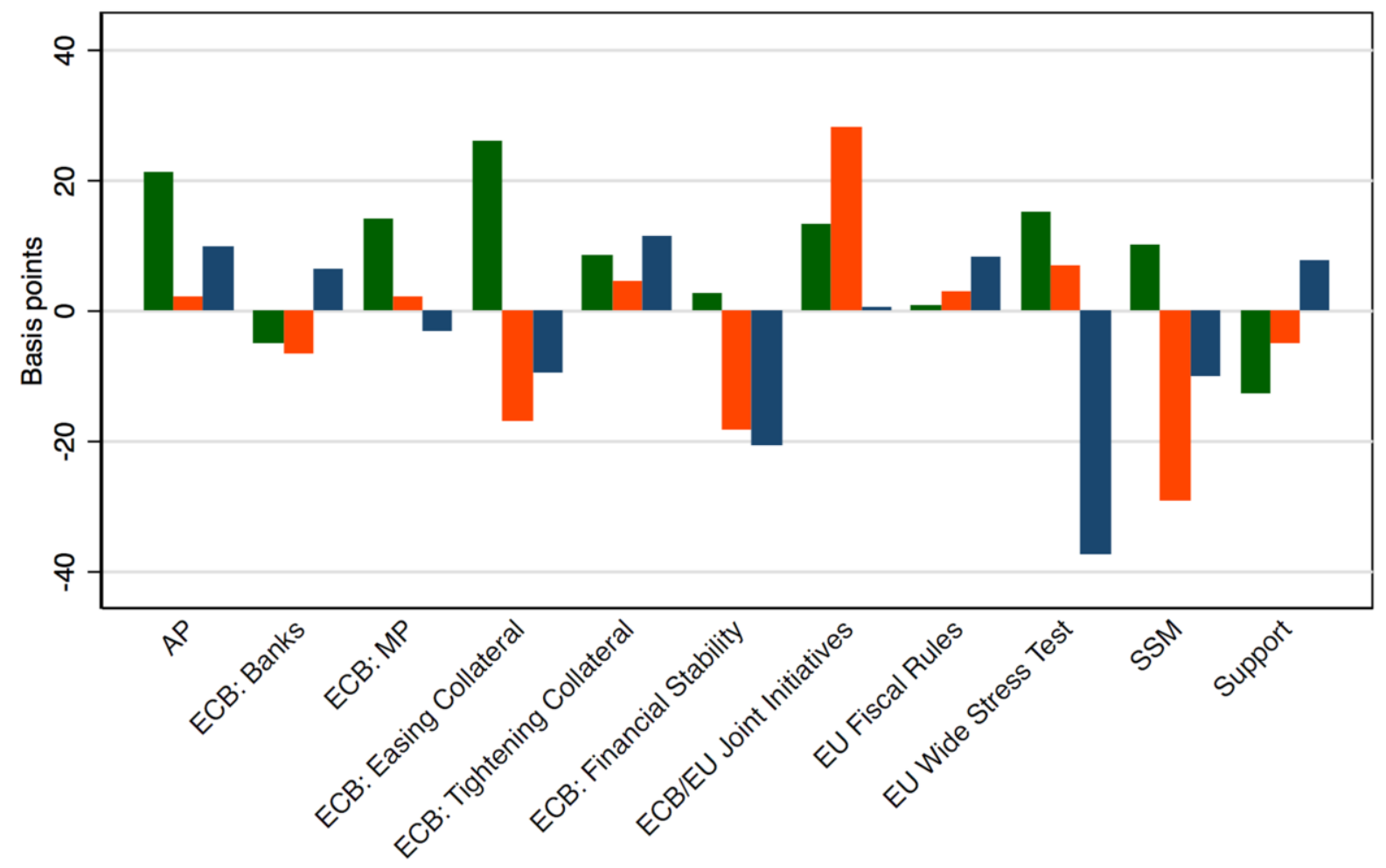

Pre-event Event $\square$ Post-event 


\section{Appendix A: Control variables.}

In Table A.1 we list the four additional national news categories for the four IIPS countries and Greece: Good (positive news about the fiscal situation in a IIPS country or in Greece), Neg (negative news about the fiscal situation in a IIPS country or in Greece), SUPPORT (EU/IMF financial assistance to a IIPS country or to Greece), CR (Fitch Rating downgrades of IIPS country or Greece sovereigns) and CR Bank (Fitch Rating downgrade of large banks in a IIPS country or in Greece) are all country specific. Note that we define positive and negative news about the fiscal situation in relation to what was expected. For example, if the budget deficit increased more than what was expected, this is considered as negative news but if the budget deficit increased less than what was expected, then this is defined as positive news. We use, as indicated above, credit rating downgrades by Fitch as our measure of the CR news announcements. These announcements also include cases when the credit rating is unchanged but the outlook for a particular country has been downgraded.

Since the literature reviewed above suggests that there is a link between the health of the banking sector and public-sector solvency we include credit rating downgrades on the largest banks in the IIPS countries and Greece. We focus on the two largest banks in each of the IIPS countries and Greece, except for Spain where we use credit rating downgrades for the three largest banks. The reason is that there are relatively few downgrades of the two largest Spanish banks over the sample, which is not reflecting the state of the banking sector properly. Therefore, we use credit rating downgrades for the third largest Spanish bank. The largest banks in Ireland are Bank of Ireland and Allied Irish Banks; in Spain Banco Santander, Banco Bilbao Vizcaya Argentaria and Banco Popular Español; in Greece National Bank of Greece and EFG Eurobank Ergasias; in Italy Unicredito Italiano and Intesa Sanpaolo; and in Portugal Banco Espirito Santo and Banco Comercial Português. The dates on credit rating downgrades are taken from Fitch Ratings homepage. ${ }^{11}$

\footnotetext{
${ }^{11}$ Fitch is the only European-based credit rating agency among the "big three." Alfonso et al. (2012) find that credit rating announcements by the three large credit rating agencies (S\&P, Moody's and Fitch) have similar effects, for both bad and good news, on government bond yields.
} 
Table A.1: Other news announcements and variables used as controls.

IIPS and Greek news announcements

\begin{tabular}{|c|c|c|}
\hline Control Variable & Definition & Example \\
\hline GOODDOM & $\begin{array}{l}\text { Positive news about fiscal situation in IIPS } \\
\text { country } \mathrm{j} \text { affecting IIPS country } \mathrm{j}\end{array}$ & $\begin{array}{l}19 \text { Apr } 2012 \\
\text { There was some relief for Spain after it saw strong demand at } \\
\text { an auction of its debt, even though some borrowing costs rose. } \\
\text { The } 10 \text {-year bonds were sold at a yield of } 5.743 \% \text {, up from } \\
5.403 \% \text { when the bonds were last sold in February. }\end{array}$ \\
\hline NEGDOM & $\begin{array}{l}\text { Negative news about fiscal situation in IIPS } \\
\text { country } \mathrm{j} \text { affecting IIPS country } \mathrm{j}\end{array}$ & $\begin{array}{l}\text { September } 30,2010 \\
\text { Ireland says its banking collapse will cost it far more than } \\
\text { expected. }\end{array}$ \\
\hline GOODFOR & $\begin{array}{l}\text { Positive news about fiscal situation in IIPS } \\
\text { country j or Greece affecting IIPS country } \mathrm{i}\end{array}$ & $\begin{array}{l}\text { June } 29,2011 \\
\text { Greece Parliament approves new austerity package. Greece's } \\
\text { parliament has passed a second vote on its austerity program, } \\
\text { which was needed to secure the country further financial } \\
\text { support. }\end{array}$ \\
\hline NEGFOR & $\begin{array}{l}\text { Negative news about fiscal situation in IIPS } \\
\text { country j or Greece affecting IIPS country i }\end{array}$ & $\begin{array}{l}\text { April } 22,2010 \\
\text { The European Union's official statistics agency says the Greek } \\
\text { budget deficit in } 2009 \text { was wider than the government had } \\
\text { estimated and adds that it has reservations about the accuracy } \\
\text { of Greek budget data that may lead to further upward revisions. } \\
\text { Eurostat said the Greek government's budget deficit was } 13.6 \% \\
\text { of gross domestic product last year. The Greek government had } \\
\text { estimated the deficit was } 12.7 \% \text { of GDP in } 2009 \text {. }\end{array}$ \\
\hline BailDom & Bailout of IIPS country $\mathrm{j}$ affecting IIPS country $\mathrm{j}$ & $\begin{array}{l}\text { November } 21,2010 \\
\text { The Irish government says it has applied for tens of billions of } \\
\text { euros in aid from the European Union and the International } \\
\text { Monetary Fund. The EU and the IMF indicate the money will } \\
\text { be forthcoming, pending negotiations on the steps to restructure } \\
\text { Ireland's debts and cut its budget deficit. }\end{array}$ \\
\hline BailFor & $\begin{array}{l}\text { Bailout of IIPS country } \mathrm{j} \text { or Greece affecting } \\
\text { IIPS country } \mathrm{i}\end{array}$ & $\begin{array}{l}\text { May } 2,2010 \\
\text { Greece reaches a historic deal with other euro-zone countries } \\
\text { and the IMF for a huge bailout, a first for one of the } 16 \\
\text { countries using the euro. The deal is expected to total more } \\
\text { than } 100 \text { billion euros ( } \$ 133.14 \text { billion) over three years, } \\
\text { though only the EU has set out its figure }-30 \text { billion euros, } \\
\text { for the first year. }\end{array}$ \\
\hline FitchDom & $\begin{array}{l}\text { Fitch credit rating downgrade of IIPS country } j \\
\text { affecting IIPS country } j\end{array}$ & $\begin{array}{l}\text { March 24, } 2010 \\
\text { Fitch Ratings lowers Portugal's sovereign credit rating by one } \\
\text { notch to double-A-minus and warns of further cuts unless the }\end{array}$ \\
\hline FitchFor & $\begin{array}{l}\text { Fitch credit rating downgrade of IIPS country } j \\
\text { or Greece affecting IIPS country i }\end{array}$ & $\begin{array}{l}\text { May 29, } 2010 \\
\text { Fitch Ratings removes Spain's triple-A credit rating, dropping it } \\
\text { by a notch to double-A-plus, on expectations that the moves to } \\
\text { cut the nation's debt will slow its economic growth. }\end{array}$ \\
\hline FBDom & $\begin{array}{l}\text { Fitch credit rating downgrade of a bank in IIPS } \\
\text { country } \mathrm{j} \text { affecting IIPS country } \mathrm{j}\end{array}$ & $\begin{array}{l}\text { April 9, } 2009 \\
\text { Fitch Ratings has today downgraded Allied Irish Banks' (AIB) } \\
\text { and Bank of Ireland's (BoI) Long-term Issuer Default Ratings } \\
\text { (IDR) to 'A-' (A minus) from 'A'. This follows yesterday's } \\
\text { downgrade of the Long-term IDR of the Republic of Ireland to } \\
\text { 'AA+' from 'AAA' and the assignment of a Negative Outlook. }\end{array}$ \\
\hline FBFor & $\begin{array}{l}\text { Fitch credit rating downgrade of a bank in IIPS } \\
\text { country j or in Greece affecting IIPS country } i\end{array}$ & $\begin{array}{l}\text { February } 23,2010 \\
\text { Fitch downgrades four major Greek banks to triple-B and } \\
\text { characterizes outlook as negative }\end{array}$ \\
\hline APFOR & $\begin{array}{l}\text { Austerity programs initiated in IIPS countries or } \\
\text { in Greece affecting other IIPS countries }\end{array}$ & $\begin{array}{l}\text { March } 3,2010 \\
\text { Greek government announces new austerity plan that will yield } \\
€ 4.8 \text { billion in savings. }\end{array}$ \\
\hline \multicolumn{3}{|c|}{ Additional control variables } \\
\hline Variable & Definition & Source \\
\hline ProbdefBanksEuro & $\begin{array}{l}\text { Probability of simultaneous default of two or } \\
\text { more banks as measured by the Systemic Risk } \\
\text { Measure }\end{array}$ & ECB \\
\hline GlobriskEuro & $\begin{array}{l}\text { Financial market liquidity indicator: Global risk } \\
\text { aversion indicator" }\end{array}$ & ECB \\
\hline VIX & VIX & FRED database \\
\hline US10ybond & $\begin{array}{l}\text { 10-Year Treasury Constant Maturity Rate, } \\
\text { Percent, Daily, Not Seasonally Adjusted }\end{array}$ & FRED database \\
\hline
\end{tabular}


Table A.2: Number of additional news announcements.

\begin{tabular}{ccccccc}
\hline & \multicolumn{5}{c}{ IIPS and Greek news announcements } \\
\hline Good & Total & Greece & Portugal & Ireland & Italy & Spain \\
Neg & 24 & 14 & 4 & 6 & 0 & 0 \\
CR sovereigns & 28 & 21 & 1 & 3 & 1 & 2 \\
CR Banks & 43 & 10 & 6 & 13 & 4 & 10 \\
\hline \hline
\end{tabular}


Table B.1: Fixed effect panel data regression with robust and clustered standard errors, CDS spreads for IIPS sovereign bonds and IIPS bank bonds.

\begin{tabular}{|c|c|c|c|c|c|c|c|}
\hline & Sovereigns & & & & Banks & & \\
\hline CDS(-1) & $\begin{array}{c}0.165 * * \\
(0.049)\end{array}$ & BailFor & $\begin{array}{c}0.041 \\
(0.355)\end{array}$ & $\mathrm{CDS}(-1)$ & $\begin{array}{c}0.049 \\
(0.024)\end{array}$ & BailFor & $\begin{array}{l}-0.423 \\
(1.217)\end{array}$ \\
\hline VIX & $\begin{array}{l}-0.591^{*} \\
(0.248)\end{array}$ & Fitchfor & $\begin{array}{c}1.199 \\
(1.005)\end{array}$ & VIX & $\begin{array}{l}-0.424 \\
(0.417)\end{array}$ & Fitchfor & $\begin{array}{c}0.612 \\
(0.335)\end{array}$ \\
\hline ProbdefBanksEuro & $\begin{array}{c}16.701 * * * \\
(1.456)\end{array}$ & FBFor & $\begin{array}{l}1.657 * * \\
(0.485)\end{array}$ & ProbdefBanksEuro & $\begin{array}{c}17.607 * * \\
(3.529)\end{array}$ & FBFor & $\begin{array}{l}-0.329 \\
(2.627)\end{array}$ \\
\hline US10ybond & $\begin{array}{c}-22.015 * * * \\
(1.609)\end{array}$ & MP & $\begin{array}{l}-2.373^{*} \\
(0.952)\end{array}$ & US10ybond & $\begin{array}{c}-3.236^{* *} \\
(0.902)\end{array}$ & MP & $\begin{array}{l}-2.435 \\
(1.547)\end{array}$ \\
\hline GlobriskEuro & $\begin{array}{c}4.401 * * \\
(1.255)\end{array}$ & SWAP & $\begin{array}{l}-0.674 \\
(0.601)\end{array}$ & GlobriskEuro & $\begin{array}{c}2.485 \\
(3.434)\end{array}$ & SWAP & $\begin{array}{c}8.600 \\
(5.550)\end{array}$ \\
\hline OMTAnnon & $\begin{array}{l}-1.386 \\
(2.176)\end{array}$ & ECBGOV & $\begin{array}{l}-1.200 \\
(1.266)\end{array}$ & OMTAnnon & $\begin{array}{c}1.530 \\
(2.246)\end{array}$ & ECBGOV & $\begin{array}{l}-1.458 \\
(2.760)\end{array}$ \\
\hline OMT & $\begin{array}{c}-13.979^{*} \\
(4.529)\end{array}$ & ECBGOVSUSP & $\begin{array}{c}3.722 \\
(1.783)\end{array}$ & OMT & $\begin{array}{c}-10.487 * \\
(3.479)\end{array}$ & ECBGOVSUSP & $\begin{array}{l}-5.098 \\
(4.278)\end{array}$ \\
\hline Draghi & $\begin{array}{l}-3.850 \\
(4.583)\end{array}$ & ECBBAL & $\begin{array}{c}3.403 * * \\
(0.693)\end{array}$ & Draghi & $\begin{array}{c}2.426 \\
(5.460)\end{array}$ & ECBBAL & $\begin{array}{l}-2.395 \\
(7.547)\end{array}$ \\
\hline SMP & $\begin{array}{c}-15.661 * * \\
(4.407)\end{array}$ & RECAP & $\begin{array}{l}-2.509 \\
(1.683)\end{array}$ & SMP & $\begin{array}{l}-10.267 \\
(6.095)\end{array}$ & Recap & $\begin{array}{l}-1.181 \\
(1.453)\end{array}$ \\
\hline APDOM & $\begin{array}{l}-0.389 \\
(0.744)\end{array}$ & FREG & $\begin{array}{l}-1.158 \\
(1.504)\end{array}$ & APDOM & $\begin{array}{c}1.355 \\
(3.433)\end{array}$ & FREG & $\begin{array}{c}0.156 \\
(1.052)\end{array}$ \\
\hline GOODDOM & $\begin{array}{c}7.332 \\
(4.319)\end{array}$ & FRESM & $\begin{array}{l}-5.515 \\
(7.786)\end{array}$ & GOODDOM & $\begin{array}{l}5.852 \\
(2.827)\end{array}$ & FRESM & $\begin{array}{c}11.397 \\
(19.643)\end{array}$ \\
\hline NEGDOM & $\begin{array}{l}-1.276 \\
(3.249)\end{array}$ & FREFSF & $\begin{array}{c}1.215 \\
(1.906)\end{array}$ & NEGDOM & $\begin{array}{c}3.292 \\
(2.745)\end{array}$ & FREFSF & $\begin{array}{c}6.522 \\
(3.470)\end{array}$ \\
\hline BailDom & $\begin{array}{l}-0.198 \\
(1.018)\end{array}$ & FRSix & $\begin{array}{l}-3.736^{*} \\
(1.299)\end{array}$ & BailDom & $\begin{array}{l}-2.347 \\
(5.712)\end{array}$ & FRSix & $\begin{array}{c}0.980 \\
(2.373)\end{array}$ \\
\hline FitchDom & $\begin{array}{l}-0.786 \\
(0.375)\end{array}$ & FRTSCG & $\begin{array}{l}-1.135 \\
(2.456)\end{array}$ & FitchDom & $\begin{array}{l}-8.348 \\
(6.263)\end{array}$ & FRTSCG & $\begin{array}{c}2.736 \\
(5.185)\end{array}$ \\
\hline FBDOM & $\begin{array}{c}3.655 * * \\
(1.028)\end{array}$ & FROther & $\begin{array}{l}-2.739 \\
(1.481)\end{array}$ & FBDOM & $\begin{array}{c}-0.890 \\
(1.295)\end{array}$ & FROther & $\begin{array}{l}-1.444 \\
(1.814)\end{array}$ \\
\hline APFOR & $\begin{array}{l}-0.675 \\
(0.756)\end{array}$ & EU Wide Stress Test & $\begin{array}{c}9.224 * * \\
(2.659)\end{array}$ & APFOR & $\begin{array}{c}0.779 \\
(1.097)\end{array}$ & EU Wide Stress Test & $\begin{array}{c}3.793 \\
(3.619)\end{array}$ \\
\hline GOODFOR & $\begin{array}{c}0.321 \\
(0.546)\end{array}$ & FRtwo & $\begin{array}{c}-24.889 * * \\
(4.920)\end{array}$ & GOODFOR & $\begin{array}{c}1.340 \\
(0.835)\end{array}$ & FRtwo & $\begin{array}{c}-17.197 * * \\
(5.233)\end{array}$ \\
\hline NEGFOR & $\begin{array}{c}0.682 \\
(0.295)\end{array}$ & SSM & $\begin{array}{l}-4.061 \\
(2.109)\end{array}$ & NEGFOR & $\begin{array}{c}1.842 \\
(0.876)\end{array}$ & SSM & $\begin{array}{l}-5.205 \\
(4.509)\end{array}$ \\
\hline Constant & $\begin{array}{l}-0.143 \\
(0.107)\end{array}$ & & & & $\begin{array}{c}0.415 \\
(0.439) \\
\end{array}$ & & \\
\hline \#countries & 4 & & & & 4 & & \\
\hline Obs & 3552 & & & & 3164 & & \\
\hline $\mathrm{R}^{2}$ & 0.40 & & & & 0.19 & & \\
\hline F-test & $64.24 * * *$ & & & & $19.90 * * *$ & & \\
\hline
\end{tabular}




\section{Appendix C: Specifics of selected policy initiatives}

Table C.1: Details on programs implemented by ECB and EU Commission/EU Parliament.

\begin{tabular}{|c|c|c|c|}
\hline Program & Announcement date & $\begin{array}{l}\text { Operational } \\
\text { specifications revealed }\end{array}$ & Implemented \\
\hline $\begin{array}{l}\text { Covered Bonds } \\
\text { Purchasing Program } \\
(\mathrm{CBPP})\end{array}$ & May 7, 2009 & June 4, 2009 & $\begin{array}{l}\text { July 6, } 2009 \text { until June } \\
30,2010\end{array}$ \\
\hline CBPP2 & October 6, 2011 & November 3, 2011 & $\begin{array}{l}\text { November } 28,2011 \text { until } \\
\text { October } 31,2012\end{array}$ \\
\hline $\begin{array}{l}\text { Securities Market } \\
\text { Program (SMP) }\end{array}$ & May 10,2010 & May 14,2010 & $\begin{array}{l}\text { May } 17,2010 \text { until July } \\
9,2010 \text { and August 16, } \\
2011 \text { until January 16, } \\
2011\end{array}$ \\
\hline $\begin{array}{l}\text { Long Term Refinancing } \\
\text { Operation (LTRO) }\end{array}$ & December 8, 2011 & December 8, 2011 & $\begin{array}{l}\text { December } 21,2011 \\
\text { February } 28,2012\end{array}$ \\
\hline $\begin{array}{l}\text { European Financial } \\
\text { Stability Facility (EFSF) }\end{array}$ & n.a. & May 9, 2010 & June 7,2010 \\
\hline Six-Pack & $\begin{array}{l}\text { September 29, } 2010 \\
\text { March 25, 2011 } \\
\text { (negotiations with EU } \\
\text { Parliament started) }\end{array}$ & November 8, 2011 & December 13, 2011 \\
\hline $\begin{array}{l}\text { European Stability } \\
\text { Mechanism (ESM) }\end{array}$ & $\begin{array}{l}\text { October } 29,2010 \\
\text { December } 17,2010 \\
\text { (political consensus } \\
\text { reached and an } \\
\text { agreement to use } \\
\text { simplified process) }\end{array}$ & $\begin{array}{l}\text { March 25, } 2011 \\
\text { (European Council } \\
\text { agreement to establish } \\
\text { ESM) } \\
\text { July 11, } 2011 \text { (ECOFIN } \\
\text { confirmed the } \\
\text { establishment of ESM) } \\
\text { July 21, 2011 } \\
\text { (modification of initial } \\
\text { proposal) } \\
\text { December 9, } 2011 \text { (a } \\
\text { second modification of } \\
\text { the proposal) } \\
\text { February 2, } 2012 \text { (the } \\
\text { addition to the Treaty } \\
\text { signed) }\end{array}$ & $\begin{array}{l}\text { September 27, } 2012 \\
\text { October 8, } 2012 \text { (ESM } \\
\text { board of governors held } \\
\text { its inaugural meeting) }\end{array}$ \\
\hline
\end{tabular}

